\title{
Long-Billed Curlew Breeding Success on Mid-Columbia River National Wildlife Refuges, South-Central Washington and North-Central Oregon, 2007-08
}

Open-File Report 2010-1089 

Long-Billed Curlew Breeding Success on Mid-Columbia River National Wildlife Refuges, South-Central Washington and North-Central Oregon, 2007-08

By Jessica Stocking, Elise Elliott-Smith, Neil Holcomb, and Susan M. Haig

Open-File Report 2010-1089

U.S. Department of the Interior

U.S. Geological Survey 


\section{U.S. Department of the Interior \\ KEN SALAZAR, Secretary}

\section{U.S. Geological Survey}

Suzette M. Kimball, Director

U.S. Geological Survey, Reston, Virginia: 2010

For more information on the USGS-the Federal source for science about the Earth, its natural and living resources, natural hazards, and the environment, visit http://www.usgs.gov or call 1-888-ASK-USGS.

For an overview of USGS information products, including maps, imagery, and publications, visit $h$ ttp://www.usgs.gov/pubprod

To order this and other USGS information products, visit http://store.usgs.gov

Suggested citation:

Stocking, J., Elliott-Smith, E., Holcomb, N., and Haig, S.M., 2010, Long-billed curlew breeding success on MidColumbia River National Wildlife Refuges, south-central Washington and north-central Oregon, 2007-08: U.S. Geological Survey Open-File Report 2010-1089, 40 p.

Any use of trade, product, or firm names is for descriptive purposes only and does not imply endorsement by the U.S. Government.

Although this report is in the public domain, permission must be secured from the individual copyright owners to reproduce any copyrighted material contained within this report. 


\section{Contents}

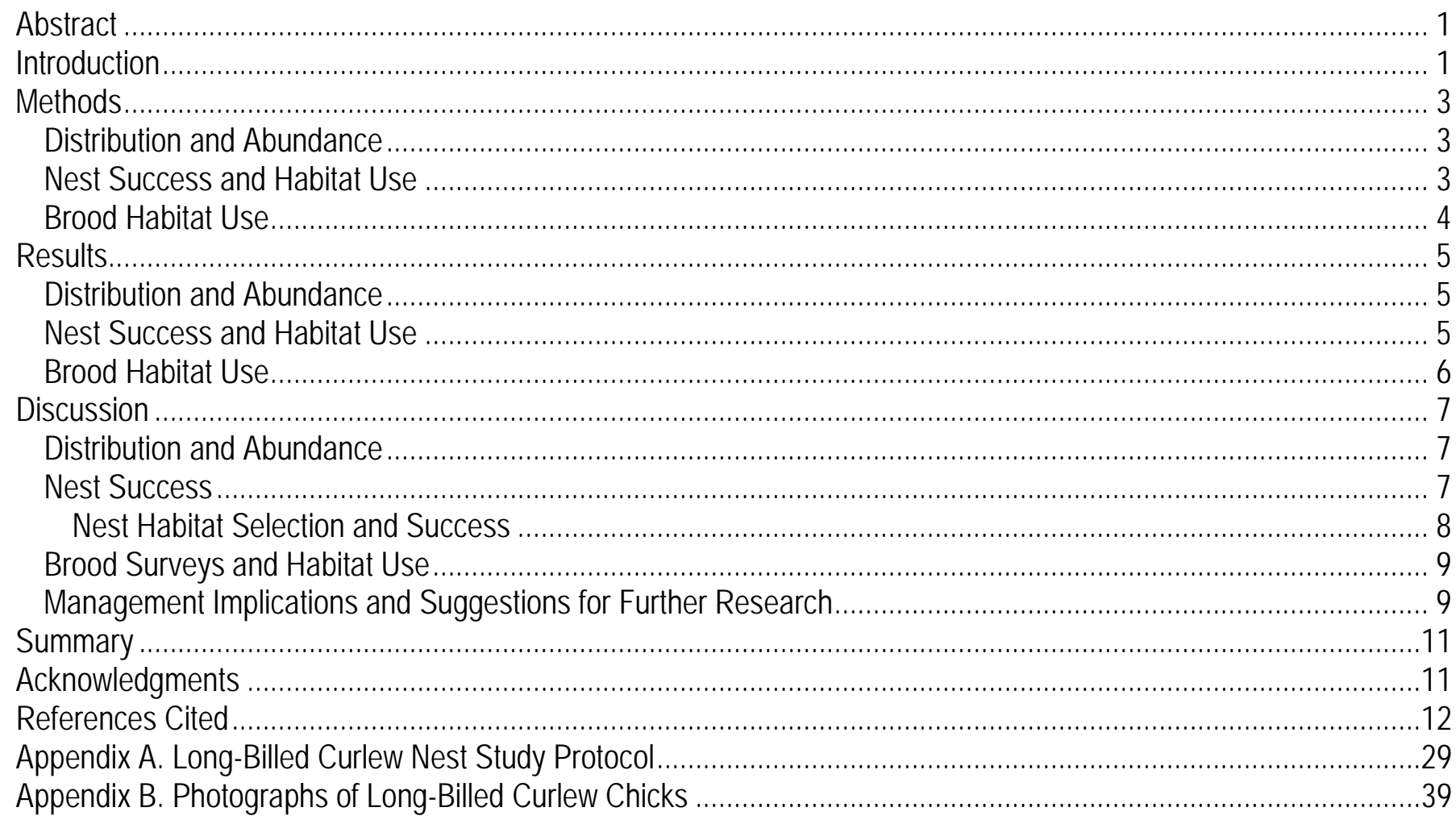

\section{Figures}

Figure 1. Rope drag efforts and nest locations at Umatilla National Wildlife Refuge, north-central Oregon and south-central Washington, 2007-08.

Figure 2. Rope drag efforts and nest locations at the ALE Unit of Hanford Reach National Monument, south-central Washington, 2007-08.

Figure 3. Rope drag efforts and nest locations at the Saddle Mountain Unit of Hanford Reach National Monument, south-central Washington, 2007-08

Figure 4. Rope drag efforts and nest locations at Columbia National Wildlife Refuge, south-central Washington, 2007-08.

Figure 5. Brood surveys and locations at Umatilla National Wildlife Refuge, south-central Washington and north-central Oregon, 2007-08.

Figure 6. Brood survey locations at the ALE Unit of Hanford Reach National Monument, south-central Washington, 2007-08. Enlarged area shows brood locations

Figure 7. Brood surveys and locations at the Saddle Mountain Unit of Hanford Reach National Monument, south-central Washington, 2007-08.

Figure 8. Brood surveys and locations at Columbia National Wildlife Refuge, south-central Washington, 2007-08

Figure 9. Daily survival probability ( \pm 2 standard errors; Johnson, 1979) of long-billed curlew nests by year and management unit on three national wildlife refuges in the Columbia Basin south-central Washington and north-central Oregon, 2007-08. 


\section{Figures-Continued}

Figure 10. Daily survival probability ( \pm 2 standard errors; Johnson, 1979) of long-billed curlew nests per year for habitat categories at 5 - and 50-m scales. Sample size is provided at the bottom of each error bar 22 Figure 11. Daily survival probability ( \pm 2 standard errors; Johnson, 1979) of long-billed curlew nests in four primary grass types at 5- and 50-m scales. Sample size is provided at the bottom of each error bar

\section{Tables}

Table 1. Curlew pair densities (pairs per hectare) for each management unit, south-central Washington and north-central Oregon, 2007-08.

Table 2. Effort, method, and number of breeding pairs and broods detected on three national wildlife refuges in the Columbia Basin, south-central Washington and north-central Oregon, 2007.

Table 3. Effort, method, and number of breeding pairs and broods detected on three national wildlife refuges in the Columbia Basin, south-central Washington and north-central Oregon, $2008 .$.

Table 4. Apparent and Mayfield nest success of long-billed curlews by year and management unit on three national wildlife refuges in the Columbia Basin, south-central Washington and north-central Oregon, 2007-08....... 27 Table 5. Mean values ( \pm 1 standard error) of vegetation characteristics for successful and unsuccessful long-billed curlew nests .....

Table 6. Long-billed curlew nest success (Mayfield method) per year by main grass components at 5- and 50-m scales

\section{Conversion Factors}

SI to Inch/Pound

\begin{tabular}{lcl}
\hline \multicolumn{1}{c}{ Multiply } & \multicolumn{1}{c}{ By } & To obtain \\
\hline centimeter $(\mathrm{cm})$ & 0.3937 & inch (in.) \\
\hline meter $(\mathrm{m})$ & 1.094 & yard $(\mathrm{yd})$ \\
\hline hectare $($ ha) & 2.471 & acre \\
\hline square kilometer $\left(\mathrm{km}^{2}\right)$ & 247.105 & acre \\
\hline square meter $\left(\mathrm{m}^{2}\right)$ & 10.76 & square foot $\left(\mathrm{ft}^{2}\right)$ \\
\hline
\end{tabular}




\title{
Long-Billed Curlew Breeding Success on Mid-Columbia River National Wildlife Refuges, South-Central Washington and North-Central Oregon, 2007-08
}

\author{
By Jessica Stocking, Elise Elliott-Smith, Neil Holcomb, and Susan M. Haig
}

\begin{abstract}
Long-billed curlew (Numenius americanus) reproductive success was evaluated on the MidColumbia River National Wildlife Refuges of south-central Washington and north-central Oregon during the 2007 and 2008 breeding seasons. Additionally, we assisted the U.S. Fish and Wildlife Service in collecting information on distribution, abundance, and brood habitat for this shorebird species of conservation concern. A total of 32 breeding pairs were located on the refuges in 2007 and 35 pairs were located in 2008. We monitored 17 nests in 2007 and 23 nests in 2008. Curlew pairs were most abundant on Hanford Reach National Monument in 2007 but more nests were located on Umatilla National Wildlife Refuge in both years, with Columbia National Wildlife Refuge supporting few pairs. Nest success was 23.6 percent in 2007 and 32.9 percent in 2008 after taking into account exposure time and combining data for all the refuges. We were unable to detect any relationship between nest success and habitat type or habitat variables measured. However, our study was the first to document use of agricultural fields on the refuge as curlew nest habitat. We collected 39 and 28 brood locations in 2007 and 2008, respectively, and many observations were likely resightings of the same brood. Broods used a similar variety of habitats as nesting curlew and no clear habitat use pattern was detected.
\end{abstract}

\section{Introduction}

The long-billed curlew (Numenius americanus) is categorized as "highly imperiled" in the U.S. Shorebird Conservation Plan due in part to historical and current population declines. It is a U.S. Fish and Wildlife Service (USFWS) Bird of Conservation Concern and was identified by the North American Bird Conservation Initiative as a species of concern in the Great Basin (Bird Conservation Region 9). There is little recent information about long-billed curlew abundance and reproductive success within the Columbia Basin; however, the long-billed curlew is a confirmed breeder. In 2007 and 2008, the U.S. Geological Survey (USGS) conducted a study to determine population status and reproductive success of long-billed curlew on federally owned lands of the Mid-Columbia National Wildlife Refuge (NWR) Complex of south-central Washington State and north-central Oregon. Results may assist the USFWS in making more informed management decisions regarding curlew breeding habitat within the Complex. 
The Columbia Basin of Oregon and Washington is a unique ecoregion because of the interspersion of remnant shrub-steppe habitats of varying quality with a high proportion of agricultural lands. Habitat on national wildlife refuges in the Columbia Basin also is quite diverse, with active farming on some refuges, native restoration programs, remnant sage-shrub patches, and large areas dominated by invasive cheatgrass. A study of long-billed curlews in the Columbia Basin conducted in the late 1970s suggested that nest density and reproductive success may be higher in cheatgrass than in other habitat types (Pampush and Anthony, 1993). One recent study in Nevada found that long-billed curlews prefer some irrigated lands over native shrub-steppe areas (Hartman, 2008). However, prior to this study, whether long-billed curlews nest on agricultural lands in Columbia Basin refuges was unknown. There was concern that breeding success potentially could be lower in agricultural fields than in other vegetation types due to disturbance caused by farming practices, such as plowing/disking, chemical application, irrigation, and harvest.

Given the conservation concern for long-billed curlews and the lack of recent information about their status within the Columbia Basin, the USGS and the USFWS developed the following five study objectives:

1. Determine distribution and abundance of long-billed curlew on national wildlife refuges in the Columbia Basin.

2. Estimate the total number and density of nesting pairs on national wildlife refuges in the Columbia Basin.

3. Characterize habitat at nest locations with respect to vegetation type, distance to nearest water, distance to active agriculture, and other pertinent variables.

4. Estimate reproductive success by comparing agricultural and shrub-steppe habitats, and comparing to previous nest success estimates for different habitat types in the northwestern U.S.

5. Provide scientific results that USFWS may use to base management actions to promote conservation of long-billed curlew on national wildlife refuges in the Columbia Basin.

During spring and summer of 2007 and 2008, the USGS worked with the USFWS in meeting the first two objectives by assisting with annual surveys and initiating surveys at Columbia NWR. Because the survey effort was ongoing and led by the USFWS, results from these surveys are not presented in this report. Instead, we present results from the USGS long-billed curlew reproductive study conducted on the refuges during both years to further improve estimates of breeding pairs and fulfill the remaining study objectives. Additionally, the USGS conducted brood surveys in both years to ensure that productivity was not underestimated and to provide the refuges with additional habitat-use information for this life stage to improve management for breeding curlews. 


\section{Methods}

\section{Distribution and Abundance}

The study area included the three refuges with nesting habitats of long-billed curlew in the Columbia Basin: Umatilla National Wildlife Refuge (NWR) (Oreg./Wash.), McNary NWR (Wash.), Hanford Reach National Monument (NM) (Wash.), and Columbia NWR (Wash.).

USFWS surveys estimated distribution and abundance and USGS surveys estimated the number of reproductive pairs in each part of the study area based on multiple behavioral observations as part of the nest searching activities. Pair estimates were then used to create approximations of density in each management unit. Suitable habitat post-season was delineated in a geographic information system (GIS, ESRI ArcMap) using digital orthophoto quadrangles in addition to habitat and burn maps provided by the refuge. In general, "suitable habitat" was defined as any area that could be categorized as some type of grass, forb, or steppe. Habitat burned in 2008 was not included as "suitable habitat" because we did not observe curlew nesting activity in any of the burned areas.

\section{Nest Success and Habitat Use}

Nest searching was done on all study areas in 2007 (figs. 1, 2, 3, and 4). Sites were selected based on historical curlew activity, detections during the USFWS surveys, and early-season searches of potential habitat. McNary NWR was excluded from the 2008 surveys due to a lack of birds observed on the refuge during the 2007 breeding season. Area searched on Hanford Reach NM was reduced in 2008 relative to 2007 due to wildfires at the end of the 2007 summer. Although burned areas were visited in 2008 and because birds were not present, we did not actively search for nests in these areas.

Focal observations and rope dragging were used to locate nests (appendix A). Observations were made from vehicles and on foot, using binoculars and spotting scopes to watch breeding displays, nest building, and search for incubating birds. Rope-dragging was done by $2-11$ observers, who pulled a rope over suspected nesting areas (or other suitable habitat), watching for an incubating curlew to flush. Nests were marked with flagging tied to vegetation, or a thin stake when vegetation was not suitable, between 25 and $40 \mathrm{~m}$ from the nest. During subsequent checks, nests were viewed from the maximum possible distance. Nest building was not often observed so the nest initiation date was calculated by back-dating incomplete clutches (Hartman and Oring, 2006) and by floating eggs of complete clutches (Westerkov, 1950; Hays and LeCroy, 1971; also see appendix A).

Habitat measurements were recorded for each nest. Maximum and mean vegetation height were estimated using a Robel pole within a 1- $\mathrm{m}^{2}$ plot centered on the nest (Robel and others, 1970). Slope and aspect, distance to the nearest tree or shrub, distance to the nearest road, distance to nearest standing water, and distance to the nearest actively irrigated agricultural field also were recorded. Vegetation measurements were taken as close to actual or predicted (in the case of nest failure) hatching dates as feasible. Distances were estimated by Global Positioning System (GPS) or in a GIS (see appendix A).

In addition to vegetation measurements, we also recorded habitat type within $5 \mathrm{~m}$ of each nest and within $50 \mathrm{~m}$ of each nest and brood. Habitat types were categorized in the field as follows:

1. Grass.-Grass-dominated fields (either bunchgrass or cheatgrass) with $<1$ percent shrub.

2. Steppe.-Grass-dominated fields with 1-30 percent shrub.

3. Forb.-Grassy fields with $>50$ percent standing annual forbs and $<1$ percent shrub.

4. Crop.-Dominated by planted and irrigated crops. 
In addition, the approximate proportions of each ground cover species were recorded for both spatial scales. Nests in Grass and Steppe habitats were further categorized by primary grass component $\unrhd 60$ percent), as cheatgrass, bunchgrass, or mixed grass habitats. Habitat patches composed of equal parts of two types, such as two grasses or grasses and forbs are labeled as such (that is, cheat/bunch).

Hatching success was determined by production of at least one chick. Curlew chicks leave the nest within hours of hatching, occasionally before the chicks are dry (Allen, 1980), making identification of unmarked broods difficult after a few days. Nest success was confirmed by the presence of young chicks and/or adult defensive behavior in the vicinity of nests immediately after hatching was predicted to occur.

Raw nest success is reported but we also corrected for differences in exposure time using the Mayfield method (Mayfield, 1975). Exposure time is the total period that a nest is observed and is calculated in days from the date the nest is first located to the date it hatches or fails. The Mayfield correction is necessary because some nests fail before they are located, and hence, raw nest success numbers may be biased high, particularly if many nests are located when close to hatching. The Mayfield method attempts to correct for this bias by calculating daily nest survival as one minus the probability of loss (which is the sum of nests lost divided by the total exposure time). Overall nest success is calculated as the daily survival probability raised to a power, where the exponent is the number of days in the nesting cycle (or stage). Daily survival probability and the overall nest success were calculated, based on a 34-day nesting stage: 6 days for laying, 27 days for incubation, and 1 day for hatching ( $\mathrm{n}=6$; 26.8 days incubation duration). Additionally, 95-percent confidence limits were calculated for the daily survival probabilities to examine effects by year, site, and habitat type (Johnson, 1979). When confidence intervals overlapped, we concluded no significant difference.

\section{Brood Habitat Use}

Brood surveys began in mid-May of both years and were conducted throughout the refuge complex and occasionally onto adjacent private land when a nest or brood was suspected in the vicinity of the refuge (figs. 5, 6, 7, and 8). Although we encountered and recorded many broods in the course of nest-searching, nest-checking, and vegetation measurement, we also conducted extensive systematic surveys using one of three methods: area search, walking transect, or driving transect. We attempted to cover as much potential habitat (grass, steppe, and any other habitat with low-growing vegetation) as possible across the entire study area, far beyond the spatial extent of our nest-searching efforts. Small habitat patches generally were covered by area searches, which involved walking a zig-zag pattern throughout potential habitat and visually searching for curlews. Larger tracts of potential habitat were covered by walking transects, which were conducted by one or more observers who walked parallel lines through suitable habitat. Where feasible, we also conducted driving transects. However, because a vehicle acts as a sort of "blind," we stopped every 200-500 m and walked at least $10 \mathrm{~m}$ from the vehicle while searching for curlew. With all three methods, observers attempted to determine the brooding status of any adult curlews encountered. Curlews defending chicks often react to observers on foot 150$400 \mathrm{~m}$ away by loudly distracting or even aggressively stooping (Dugger and Dugger, 2002), and this response is easily distinguished from the behavior of non-breeding or incubating birds.

Adults that aggressively defended a particular locale were considered to be defending a brood. We attempted to locate chicks so that we could determine their age. Young chicks less than 5 days old were assumed to have hatched on the refuge. When possible, we recorded whether a brood was likely from a nest we had monitored. All breeding attempts first found during the chick stage were omitted from the nest success analysis. 
The location of each brood was recorded in addition to habitat type. When chicks were found, we recorded their exact location with a Garmin@ GPS unit (various models used). When chicks were not found, we recorded location as the approximate center of the area defended by adult curlews. Habitat type and proportions of ground cover types also were recorded within $50 \mathrm{~m}$ of each brood waypoint, and were classified in the same manner as for nests (see above).

\section{Results}

\section{Distribution and Abundance}

Estimates of breeding pairs in each management unit (tables 1, 2, and 3), based on nest searches and estimates of suitable habitat (table 1), suggest that curlew pairs were most dense in the McCormack South Unit of Umatilla NWR. The search effort was not equal in all areas; because our primary objective was monitoring nests, we spent more time searching for nests in areas with the greatest number of pairs. Columbia NWR was omitted from the density calculations due to the fragmented nature of the refuge and resulting inability to confirm pair use of the refuge for nesting. Umatilla NWR may be an initial staging area for breeding curlews in this region, as several large (30+ individuals) flocks were observed on the McCormack Unit during the first 2 weeks of arrival in each year, but many of these birds did not remain to breed. Because birds were not banded, we were not able to tell if these flocks were comprised of birds that ultimately nested elsewhere on refuge lands or settled outside the study area. Suitable habitat at Saddle Mountain and Hanford Reach NM Arid Lands Ecology Reserve (ALE) decreased from 2007 to 2008 due to fires that rendered some habitat unsuitable in 2008.

\section{Nest Success and Habitat Use}

Nineteen and 23 nests were located in 2007 and 2008, respectively: 26 were located on Umatilla NWR, 12 on Hanford Reach NM, and 4 at Columbia NWR (figs. 1, 2, 3, and 4). Seventeen nests were located by focal observation (12 in 2007 and 5 in 2008) and 23 nests were found by rope dragging (5 in 2007 and 18 in 2008). Rope dragging covered 5,189 km² in 2007 and 8,361 km² in 2008 . Two nests in 2007 were located on Umatilla NWR by detection of a young ( $<5$ day old) brood and subsequent location of associated nests, but these were omitted from nest success analyses. Of 40 nests found prior to or during hatch, 18 hatched, 20 were depredated, and 2 were abandoned (45 percent overall apparent hatching success). Two of the depredated nests appeared to represent a single clutch; after a one-egg nest was depredated, the clutch was apparently completed as a three-egg clutch in a second nearby nest. If we considered those to be a single nesting attempt, overall hatching success would have been 46 percent. However, this is speculative, so they are considered separate attempts for the remaining analyses.

Apparent nest success was 41 and 48 percent in 2007 and 2008, respectively, but after taking into account the total exposure time, nest success was estimated to be 23.6 and 32.9 percent (Mayfield 1975; table 4). Overall, daily survival probability was calculated to be 0.958 in 2007 and 0.9679 in 2008. There was no significant difference in daily survival probability between years or between refuges, although sample size was small, particularly on Columbia NWR (fig. 9).

Of the eight habitat measurements taken at nests, each exhibited high variability among nests. There was no significant difference between habitat measurements at successful and unsuccessful nests (table 5). Vegetation measurements were not recorded for one unsuccessful nest in an alfalfa field at Columbia NWR (2008), and the nest has been excluded from table 5. 
At the 5-m scale, 30 nests were in grass (75 percent), 6 in crop (15 percent), 2 in steppe (5\%) and 2 in forb (5\%). At the 50-m scale, 16 nests were located in grass (40 percent), 16 in steppe (40 percent), 6 in crop (15 percent), and 2 in forb (5 percent). The six nests in irrigated crop fields were in timothy (two in 2007), green, irrigated cheatgrass in an unplanted section of a buckwheat field (three in 2008), and alfalfa (one in 2008). Daily survival probability did not differ significantly between habitat types at either the 5- or 50-m spatial scale (fig. 10).

For most nests categorized in grass or steppe habitat, the dominant grass type in the vicinity of the nest and at the 50-m scale was cheatgrass (table 6). Nests located in short grass of indeterminate composition were omitted from the analysis of grass habitats (one in 2007 at the 5-m scale, three in 2007 at the 50-m scale). We were unable to detect any significant difference in nest success related to grass type, likely due in part to small sample size (fig. 11).

\section{Brood Habitat Use}

Brood surveys covered 76,602 $\mathrm{km}^{2}$ in 2007 and 39,719 $\mathrm{km}^{2}$ in 2008. This was more area than the nest study due to the relative ease of finding broods versus nests by parental behavior. However, area surveyed in 2008 was smaller relative to 2007 due to omission of habitat with no curlew nesting activity and fires on Hanford Reach NM rendering some habitat unsuitable. Thirty-nine and 28 locations of broods were obtained in 2007 and 2008, respectively (figs. 5, 6, 7, and 8). In 27 instances, we observed at least one chick (range: $1-5 ; \mu=2$ ), and in some instances, there were more than two adults in the vicinity engaged in defensive displays elicited by our approach. In the remaining 40 observations, brood locations were determined based on adult behavior but we were unable to locate chicks. Chicks observed were between 1 day and 3 1/2 weeks old, and no chicks were observed fledged due to length of the study (that is, study ended prior to the time chicks would have fledged). Thirty observations of broods were identified as having originated from 16 nests. Thirty-four observations were of broods not associated with any particular nest, but in these instances, chicks were old enough to have moved away from a known nest. Due to the numerous resightings involved in the known-nest observations, a large number of the unknown-nest observations likely were resightings. Three young broods ( $<5$ days old) were found that did not appear to have hatched from known nests. In two instances, suspected nests were located by searching the area near the broods. In the third instance, the brood is suspected to have hatched on nearby private land.

Habitat within $50 \mathrm{~m}$ of brood locations ( $\mathrm{n}=67)$ consisted of 39 percent steppe $(\mathrm{n}=26), 28$ percent crop ( $n=19), 27$ percent grass $(n=18), 4.5$ percent mixed $(n=3)$, and 1.5 percent forb $(n=1)$. Brood locations within steppe habitat consisted of 1-25 percent shrubs, $0-35$ percent forbs, with the grass type entirely cheatgrass (58 percent; $n=15$ ), bunchgrass ( 4 percent; $n=1$ ), or a mixture cheatgrass of bunchgrass (38 percent; $n=10$ ). Crop locations consisted of timothy, buckwheat, recently-cut alfalfa, and corn. Grass locations were in cheatgrass fields with 5-20 percent forb, except two locations: one in a recently burned field dominated by grass stubble and bare ground, and the other in an area dominated by bunchgrasses with bare dirt and forbs. 


\section{Discussion}

\section{Distribution and Abundance}

We are confident in our estimates of long-billed curlew pairs using the refuge in 2007 and 2008. If there had been many additional pairs breeding on the refuges with nests we did not find, we likely would have detected them on brood surveys. However, only three observations of broods may have nested on the refuge but escaped detection during nest searches. Additionally, there may have been pairs that nested on the refuge unsuccessfully but escaped detection. Estimates of nest success suggest that there could have been an additional 7-10 pairs on the refuge whose nests were not found.

We observed 8 fewer pairs nesting on Hanford Reach NM in 2008 and 11 more pairs on Umatilla NWR and Columbia NWR relative to 2007. A recent satellite telemetry study suggests that curlew return to the same general breeding areas from one year to the next (Gary Page, PRBO Conservation Science, oral commun., 2009). Thus, the decrease in curlew nesting activity observed at Hanford Reach NM is likely due to fires in late summer of 2007. Although these areas are likely to provide habitat in the future, they were barren in 2008 and were not used by nesting curlew. Slight increases in curlew nesting activity observed on the other refuges in 2008 may have included pairs that had nested on Hanford Reach NM in 2007, but because birds were not banded, we can only speculate on movement patterns.

It is difficult to determine whether there has been a change in curlew abundance on the refuge over time. We can not directly compare between our density estimates to those of Pampush (1980) in the 1970s because of different study areas. Our density estimates were substantially lower $(\leq 0.01$ nesting pairs per ha) than a mean observed nest density of 3.6 per 40-ha plot (0.09 nests per ha) reported by Pampush (1980). This is likely due to our use of all seemingly suitable habitat (defined as grass, forb, or steppe) in density calculations (table 1). However, we did have areas where nesting pairs were clustered on Umatilla NWR, and if we had calculated nest density for these specific areas, it likely would have been much closer to Pampush's estimates. It is unclear whether Pampush's plots were specifically placed in areas with curlew abundance or randomly placed among available habitat types (Pampush, 1980).

Our intensive nest monitoring suggests that the timing of annual surveys is critical to accurate abundance estimates. The arrival of long-billed curlews into the study area was consistent with several previous years of observations, averaging within a day of March 15 at the southern end of the study area (Heidi Newsome, USFWS, oral commun., 2007). However, the presence of large groups (30+) of curlews at Umatilla NWR in mid- to late March that did not remain there to breed suggest that abundance may be over-estimated if surveys are conducted too early. Hartman (2008) counted twice as many curlews migrating through a study area in Nevada than bred there. Incubating pairs are difficult to detect because they stop displaying. Thus, the 1-2 week optimal survey window is very narrow. Furthermore, the date of this window may vary annually due to weather patterns.

\section{Nest Success}

Nest success estimates from the late 1970s appear higher than our overall nest success in either 2007 or 2008, but this is difficult to confirm. Curlew nest success as calculated with the Mayfield (1975) method in 1978-79 was 0.69 and 0.65 (Pampush and Anthony, 1993), which is about twice as high as estimates during both years of our study ( 0.24 and 0.33 , respectively). However, direct comparison of these estimates is complicated because Pampush does not give number of days used in 
calculations of nest success and does not calculate confidence limits for daily survival probability. Our overall nest success is similar to that in a 4-year study in Nevada (average 0.31; range: 0.20-0.51), calculated using Schaffer's known fate logistic-exposure method (Hartman, 2008). Our overall nest success also is similar to nest success during a recent 2-year study in South Dakota (Mayfield nest success was 0.39 in 2005 and 0.15 in 2006, and Program MARK daily survival rate was 0.94 for both years combined; Clarke, 2006).

Our overall nest success also may include some re-nesting attempts as recent research confirms that long-billed curlew may re-nest in some areas if the first attempt is unsuccessful (Hartman and Oring, 2009). Birds were not marked in this study, so re-nests could not be confirmed. The most compelling evidence of re-nesting in 2008 occurred on the McCormack and ALE units, where lined nests $(\mathrm{n} \geq 5)$ were found within $50 \mathrm{~m}$ of active nests. Although curlews, along with other shorebirds, will make multiple scrapes in a territory before choosing one in which to nest (Dugger and Dugger, 2002), the presence of lined scrapes suggests they may have actually been used as a nest. .

We did not find any difference in nest success between the years or refuges, but few birds nested on the refuges, making it difficult to statistically detect meaningful differences when they exist. For example, with sample sizes of fewer than 10 nests per year on Hanford NWR and Columbia NWR, it would have been almost impossible to find a statistical difference in nest success. However, because we likely located a high proportion of nests on each refuge, direct comparison of nest success may be valid (without statistical significance), but interpretation is limited. For example, we can say with confidence that overall nest success in 2008 on Columbia NWR was lower than the other refuges. Our sample size was only two nests on Columbia NWR, but it is unlikely that there were any additional nests on the refuge and both nests failed. However, because the sample size was so small, 100 percent failure is not meaningful, and it would be inappropriate to make inferences about the quality of nesting habitat or source-sink dynamics based on such limited data.

Nest Habitat Selection and Success

Our findings are consistent with curlews nesting in sites with a low vertical profile (Allen, 1980; Jenni and others, 1981; Pampush and Anthony, 1993; Dugger and Dugger, 2002) and vegetation of low structural complexity (Pampush and Anthony, 1993), but we did not quantify habitat selection as a function of availability. Many nests categorized as steppe at the 50-m scale were in grass at the 5-m scale, suggesting that curlews may avoid shrubs or select grassy patches on a microhabitat scale. Pampush and Anthony (1993) found that curlews in north-central Oregon preferred cheatgrass. We found more nests in grass at the 5-m scale than in steppe, crop, or forb combined, and nests located in grass habitat were more often in cheatgrass than in bunchgrass, cheat/bunch, or cheat/forb. This could suggest selection for cheatgrass but also could be explained by a predominance of cheatgrass in those units.

In addition to a preference for cheatgrass habitat, Pampush and Anthony (1993) suggest that nest success may be higher in cheatgrass-dominated habitat than in other habitat types. Our data does not support this finding; our nest success appeared equal or higher in bunchgrass than in other habitat types but our sample size was small and there was much overlap in the daily survival probability between habitat types (fig. 11). In dry dense cheatgrass and/or short forbs, we observed that curlews sometimes leave a visible trails to the nest. Such trails were not obvious in irrigated fields, in native bunchgrass, or in those few areas where cheatgrass did not grow densely. As predators may be able to detect visible trails, this might suggest that curlews are more vulnerable to predation in cheatgrass habitat. Furthermore, although we attempted to minimize visits to the nests, researchers also left footpaths through cheatgrass fields and these paths or scent trails could affect nest success. 
None of the habitat variables examined in this study (for example, vegetation height and distance to water) appeared to be related to nest success. Although our sample size was small, there was great overlap in all measurements, suggesting that any of the habitat variables measured likely are not related to nest success. Other variables not measured in this study possibly may affect nest success or perhaps there is a combination of factors that act synergistically to influence habitat quality. Although we were unable to find any differences in nest success, some of the variables measured could influence habitat selection. However, in order to better understand selection, habitat measurements at nests should be compared with random sites.

Although we were not able to evaluate nest success on agricultural land compared to other habitat types, this study is the first to confirm curlew nesting on agricultural land in the Columbia Basin. Nests were located in fields of buckwheat and timothy (same field, consecutive years) at Umatilla NWR and alfalfa at Columbia NWR. The alfalfa nest was abandoned, presumably due to dense vegetation that exceeded $20 \mathrm{~cm}$ at the time of abandonment. For three nests found in 2008, refuge staff created a 30-m buffer around the nest that was not sprayed or disked, although the remainder of the field received those treatments. Two of the nests hatched, and chicks used the non-disked areas for the first 2 weeks after hatching. This suggests that the 30-m buffer was sufficient for successful breeding, but further field and toxicological studies may be warranted to determine an appropriate buffer size. Discovery of nests in crops supports anecdotes from local farmers regarding their finding of curlew eggs and young chicks in unharvested potato, corn, and alfalfa fields. Observers were not able to search for nests in the areas of Umatilla NWR where wheat was planted; consequently, curlew use of wheat lands is unknown..

\section{Brood Surveys and Habitat Use}

We covered large expanses of potential habitat during brood surveys relative to nest searches, but our brood surveys indicate that nest searches identified most pairs and nests. As previously mentioned, brood surveys located an additional three pairs with $<5$ day-old chicks and at least two of these pairs likely nested on refuge land. Given our reproductive success (23.6 and 32.9 percent in 2007 and 2008, respectively), we can estimate that there may have been 9-13 additional unsuccessful nesting attempts on refuge lands that we failed to detect. There is not likely additional habitat on the refuges where curlew could have nested undetected.

Our brood surveys did not reveal any clear habitat use patterns or preferences. Pampush and Anthony (1993) found that adult curlews (with and without broods) in 1978-79 preferred cropland in a Umatilla NWR transect. In our study, cropland was used for brood-rearing more than nesting, but cropland was not the most commonly used brood-rearing habitat. Nesting pairs also may rely on cropland for foraging. However, we were unable to quantify habitat use of nesting pairs when off the nest.

\section{Management Implications and Suggestions for Further Research}

Given the narrow window optimal for surveying, caution must be exercised in interpreting the results of the annual surveys. Furthermore, as long-billed curlews are short-distance migrants, their migration timing may be dependent on current weather patterns, which may render them particularly sensitive to climate change (Murphy-Klassen and others, 2005; Miller-Rushing and others, 2008). Hence, the timing of this optimal survey window may become earlier and perhaps more annually variable. The additional potential of migrants in the region further confounds survey results. In order to 
accurately quantify the breeding population, surveys must be conducted when the number of curlew in the populations seems relatively stable. Hence, two or more surveys may be needed to obtain accurate abundance estimates. A pre-survey visit also may be useful to confirm that curlews have returned to the region so that refuge staff and assistants do not spend time surveying with zero detections.

In future studies of nest density and success, we recommend a combination of focal observation and extensive rope-dragging to find nests in an effort to increase sample size. Nests were located primarily by focal observation in 2007 and by rope dragging in 2008. Focal observations are effective primarily during the 3 weeks after the first curlew arrivals in March, although rope dragging is effective throughout incubation. Surveyors should determine locations of displaying curlews shortly after arrival, locate nests by focal observation, and then rope-drag to find remaining nests. Areas may need to be rope-dragged more than once in a season to locate later nest initiations, including re-nesting attempts. In order to increase sample size, studies should incorporate more of the surrounding areas (Boardman Bombing Range, D.O.E. Hanford site, etc.; Allen, 1980; Pampush, 1980; USFWS survey data for appropriate locations). Banding individual birds would assist in determining if broods detected during brood surveys were from nesting attempts on refuges or if broods move into refuge areas after hatching. Banding individual birds also would assist in determining reuse of territories between years and movement of individuals among refuge locations.

Our discovery of long-billed curlews nesting on agricultural fields suggests this habitat may be managed to promote curlew conservation. Some guidelines are already in place that govern agricultural practices on refuges and may serve to protect curlews. For example, refuge policy dictates that fields be disked by early spring. If fields with short vegetation are disked prior to March 15, they will be unsuitable when curlews return from migration so curlews will not set up territories or nest in these disked areas. However, in 2008, disking was delayed on one field and two curlew nests were located there early in the season; had we not found these nests, they likely would have been destroyed when the farmer disked later in the spring. In addition to disking, cutting fields and moving equipment during the breeding season has the potential to destroy nests and also may harm chicks because their behavioral response is to freeze rather than run (Dugger and Dugger, 2002). This is particularly likely on fields with suitable habitat during the nest initiation period (short vegetation sometime during late Marchmid-May). However, cutting fields with tall vegetation later in the breeding season may create new habitat for curlew broods. If disking or cutting agricultural fields is necessary during the curlew nesting season, the USFWS may be able to determine the presence of breeding curlew by rope-dragging the area twice during the nesting period (from late March through mid-June) and checking for broods during the brood-rearing phase (through the end of June). If curlew nests are found, then buffers of at least $30 \mathrm{~m}$ could be created around nests similar to the buffers created around the two nests we found in 2008 (where the remainder of the field was disked and sprayed). However, further research is recommended to determine the appropriate buffer size.

On non-agricultural refuge lands, our analyses were based on small sample sizes and did not yield statistically significant differences among habitats in curlew use or nest success. Our results are qualitatively consistent with Pampush and Anthony's (1993) finding that curlews prefer cheatgrass habitat for nesting, but it is unclear whether our results are consistent with their finding that nest success is higher in cheatgrass than other habitat types. Given that a management focus of the Mid-Columbia Refuge Complex is to control cheatgrass and plant native perennial bunchgrass, it might be worthwhile to conduct a larger study of nest success on and off refuge lands with a sample size more likely to detect differences between cheatgrass and other habitats. Results could clarify how native plantings on the refuge might affect curlew conservation. Comparing nest success in mixed cheat/bunch with other habitats also may provide information on the effects of rigorous cheatgrass control to nesting curlew. 
In addition to conducting a reproductive study on and off of refuge lands, it may be worthwhile to examine historical changes in curlew habitat availability in the region and assess how these changes have impacted curlew populations. Agricultural practices in the ecoregion containing the study area have undergone significant changes recently and likely will continue to do so. Similar to privately owned lands, current high crop prices have influenced refuge decisions regarding conversion of cooperatively farmed agricultural grasslands to production of wheat and corn. Additionally, agriculture on the region's refuges is greatly influenced by the mission of providing habitat for both migrating and over-wintering waterfowl. In order to better estimate curlew abundance on a landscape level, investigators could estimate their relative abundance in different habitat types on the refuge including different crop types.

A radio-telemetry study would be useful to discover how far birds travel from their nest site and clarify habitat needs on a landscape level. Curlews have been documented traveling from their defended territory to forage (Pampush and Anthony, 1993), and we also observed curlews flying far from their nesting area. McCallum and others (1977) proposed that the prairie habitat did not explain curlew distribution in Colorado and suggested that distance to water may be a factor in nest site selection. In our study, distance to standing water did not appear related to nest success. However, a telemetry study could further clarify the importance of nearby water as we could determine the frequency and duration of the time spent at water in addition to the distance curlews regularly fly from their nest sites.

In addition to increased future monitoring and a telemetry study, cameras at nest sites could be used to quantify the relative impact of different predators. If mammalian predators (particularly coyote) are suspected to be a significant predator on the refuge, further study efforts might consider efforts to mask human scent at nest visits (Allen, 1980; Redmond and Jenni, 1986). Understanding the role of non-native predators to curlew nest success also will inform any discussions and decisions on predator control.

\section{Summary}

Long-billed curlew reproductive success on the Mid-Columbia River NWR's was 23.6 percent in 2007 and 32.9 percent in 2008, which is similar to productivity estimates from studies conducted elsewhere, but may reflect a decrease in productivity when compared to estimates from a late-1970's study conducted in the same geographic region. Due in part to small sample size ( $n=17$ in $2007 ; n=23$ in 2008), we were unable to detect any relationship between nest success and habitat type or habitat variables but we were able to confirm nesting on agricultural lands. Curlew brood locations also included a variety of habitat types. To better understand the importance of native plantings and cheatgrass control on nesting curlew, a larger study is necessary and this would require including areas outside the refuge. Additional research, such as a telemetry study and videotaping nests could provide valuable information to guide refuge management practices aimed at protecting and promoting the longbilled curlew.

\section{Acknowledgments}

We would like to thank the USFWS for their support and guidance of the project. USFWS biologists Heidi Newsome, Howard Browers, and Randy Hill provided orientation, field support, and solicitation of staff and volunteer assistance. In addition to the authors, Sidra Blake, Jesse Conklin, and Jason Ziegler provided invaluable assistance in collecting field data. Jesse Conklin also summarized the first year of data, and we have drawn from his annual report in preparing this report. Thank you also to the volunteers, without who nest searching would have been noticeably less thorough. 


\section{References Cited}

Allen, J.N., 1980, The ecology and behavior of the long-billed curlew in southeastern Washington: Wildlife Monographs, v. 73, p. 1-67.

Clarke, J.N., 2006, Reproductive ecology of long-billed curlews breeding in grazed landscapes of western South Dakota: Brookings, South Dakota, M.S. thesis, South Dakota State University, Brookings.

Dugger, B.D., and Dugger, K.M., 2002, Long-billed curlew (Numenius americanus), in Poole, A., and Gill, F., eds., The Birds of North America, n. 628: Philadelphia, Pennsylvania, The Birds of North America, Inc.

Hartman, C. A., and Oring, L.W., 2009, Reproductive success of long-billed curlews (Numenius americanus) in northeastern Nevada hayfields: Auk, v. 126, p.420-430.

Hartman, C.A., 2008, Behavioral ecology and population biology of long-billed curlews (Numenius americanus) in northeastern Nevada: Reno, Nevada, Ph.D. dissertation, University of Nevada, Reno. Hartman, C.A., and Oring, L.W., 2006, An inexpensive method for remotely monitoring nest activity: Journal of Field Ornithology, v. 77, p.418-424.

Hays, H., and Lecroy, M., 1971, Field criteria for determining incubation stage in eggs of the Common Tern: Wilson Bulletin, v. 83, p. 425-429.

Jenni, D.A., Redmond, R.L., and Bicak, T.K., 1981, Behavioral ecology and habitat relationships of long-billed curlew in western Idaho: Boise, Idaho, Department of the Interior, Bureau of Land Management, Boise District.

Johnson, D.H., 1979, Estimating nest success: The Mayfield Method and an alternative: Auk, v. 96, p. 651-661.

Mayfield, H.F., 1975, Suggestions for calculating nest success: Wilson Bulletin, v. 87, p. 456-466.

McCallum, D.A., Graul, W.D., and Zaccagnini, R., 1977, The breeding status of the long-billed curlew in Colorado: Auk, v. 94, p. 599-601.

Miller-Rushing, A.J., Lloyd-Evans, T. L., Primack, R.B., and Satzinger, P., 2008, Bird migration times, climate change, and changing population sizes: Global Change Biology, v. 14, p. 1959-1972.

Murphy-Klassen, H.M, Underwood, T. J., Sealy, S.G., and Czyrnyj, A.A., 2005, Long-term trends in spring arrival dates of migrant birds at Delta Marsh, Manitoba, in relation to climate change: Auk, v. 122, p. 1130-1148.

Pampush, G.J., 1980, Breeding chronology, habitat utilization and nest-site selection of the long-billed curlew in north-central Oregon: Corvallis, Oregon, M.S. thesis, Oregon State University.

Pampush, G.J., and Anthony, R.G., 1993, Nest success, habitat utilization and nest-site selection of long-billed curlews in the Columbia Basin, Oregon: Condor, v. 95, p. 957-967.

Redmond, R.L., and Jenni, D.A., 1986, Population ecology of the long-billed curlew (Numenius americanus) in Western Idaho: Auk, v. 103, p. 755-767.

Robel, R.J., Briggs, J.N., Dayton, A.D., and Hulbert, L.C., 1970, Relationships between visual obstruction measurements and weight of grassland vegetation: Journal of Range Management, v. 23, p. 295-297.

Westerkov, K., 1950, Methods for determining the age of game bird eggs: Journal of Wildlife Management, v. 14, p. 56-67. 


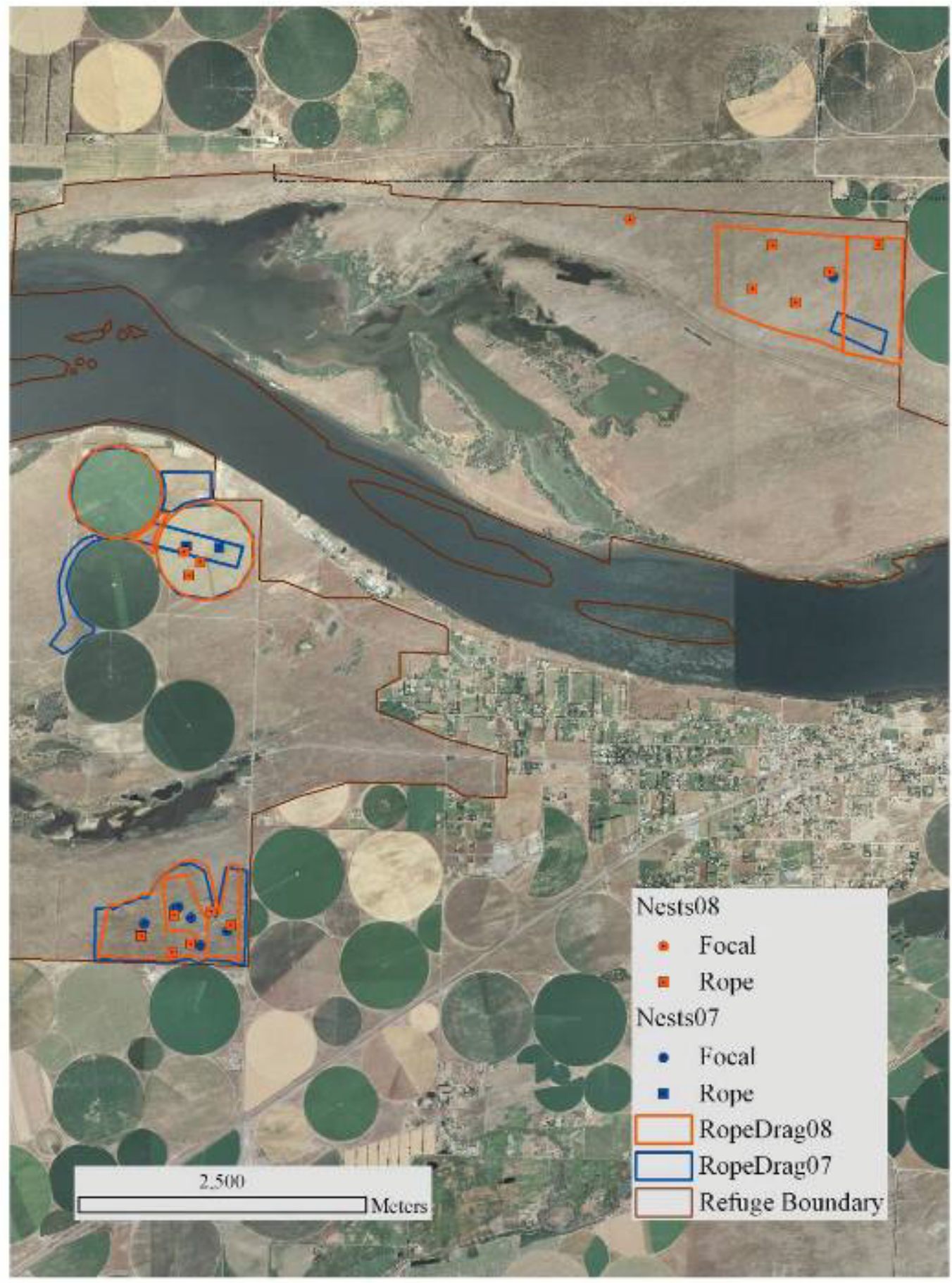

Figure 1. Rope drag efforts and nest locations at Umatilla National Wildlife Refuge, north-central Oregon and south-central Washington, 2007-08. 


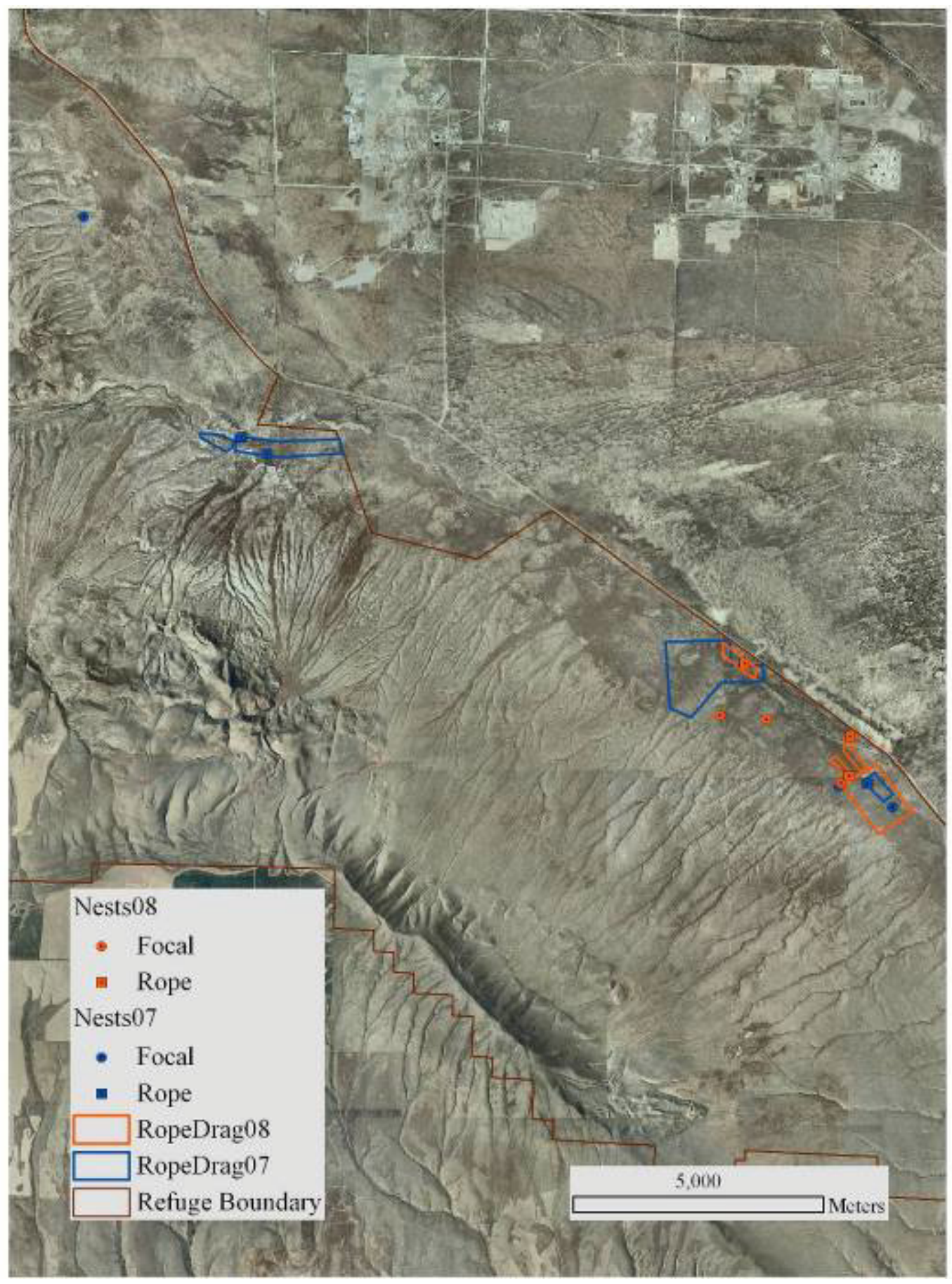

Figure 2. Rope drag efforts and nest locations at the ALE Unit of Hanford Reach National Monument, south-central Washington, 2007-08. 


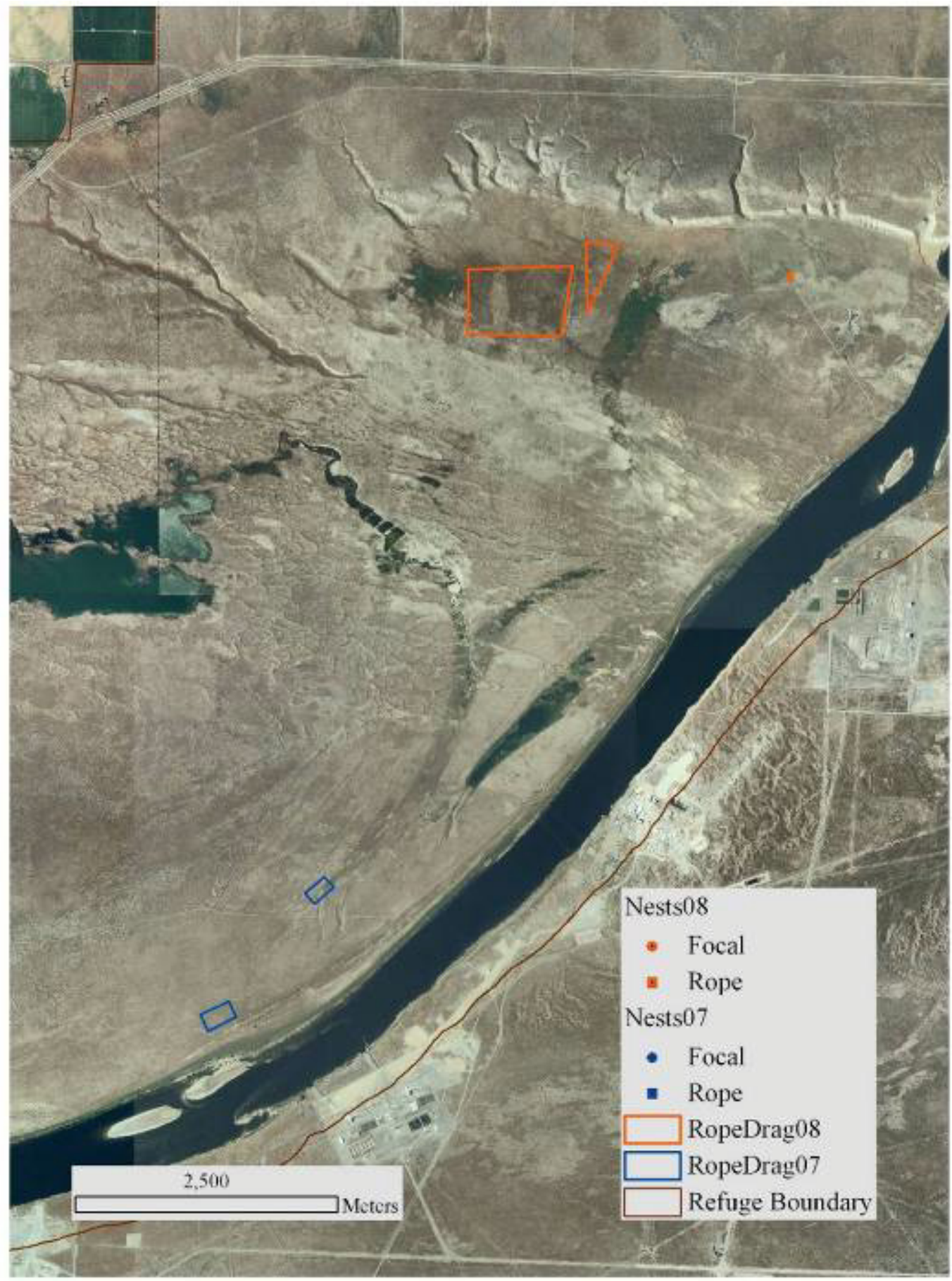

Figure 3. Rope drag efforts and nest locations at the Saddle Mountain Unit of Hanford Reach National Monument, south-central Washington, 2007-08. 


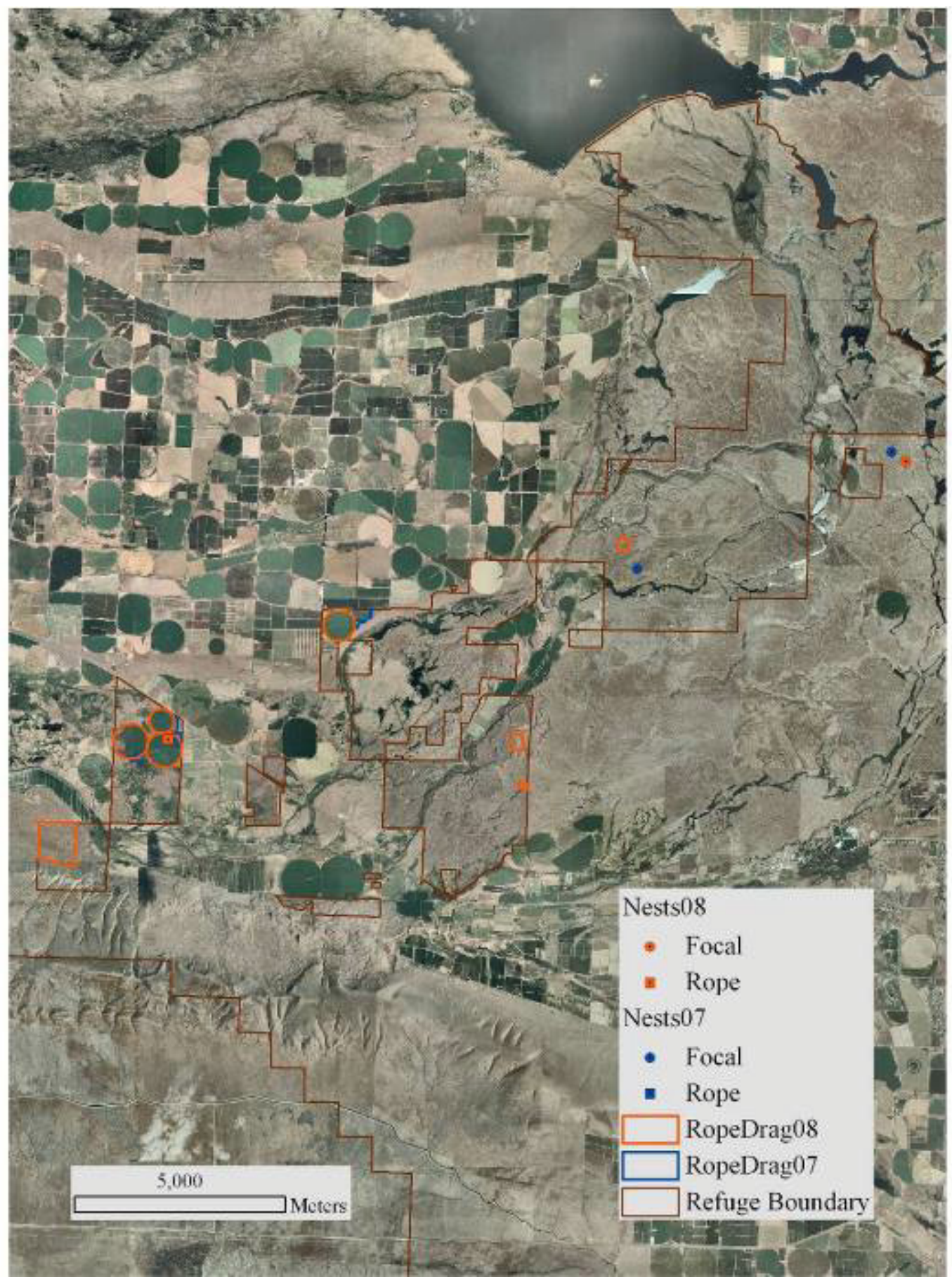

Figure 4. Rope drag efforts and nest locations at Columbia National Wildlife Refuge, south-central Washington, 2007-08. 


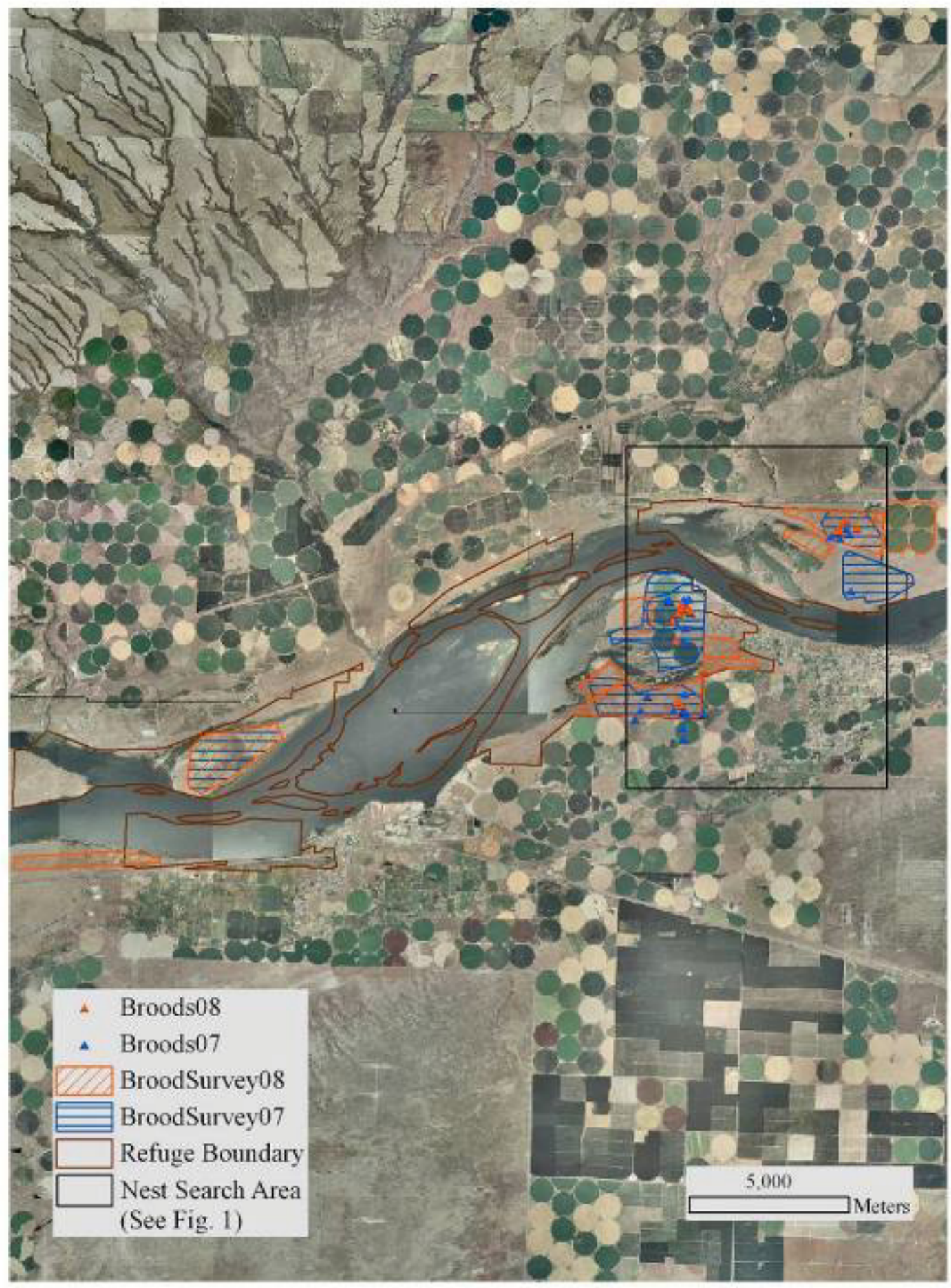

Figure 5. Brood surveys and locations at Umatilla National Wildlife Refuge, south-central Washington and north-central Oregon, 2007-08. 


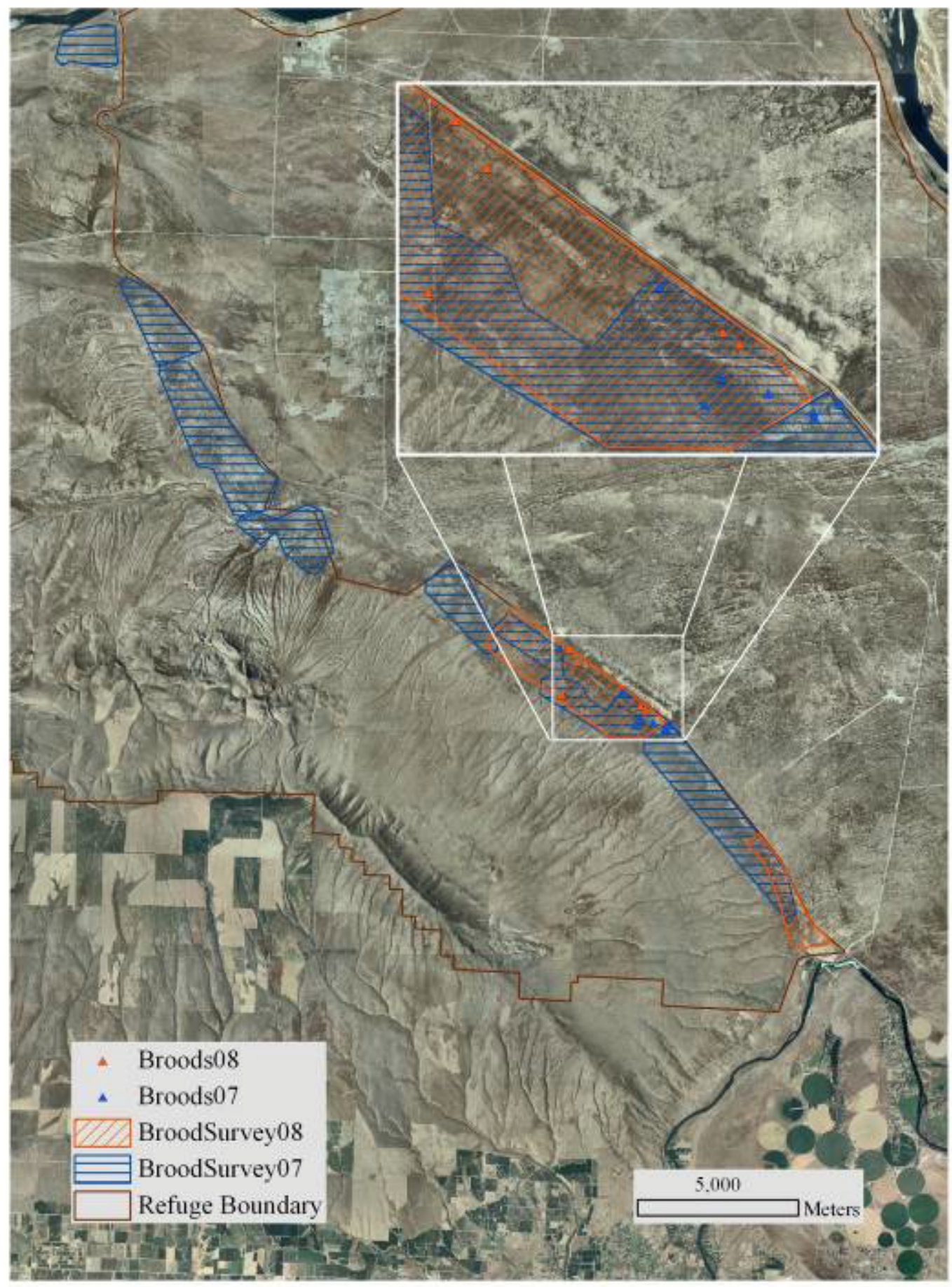

Figure 6. Brood survey locations at the ALE Unit of Hanford Reach National Monument, south-central Washington, 2007-08. Enlarged area shows brood locations. 


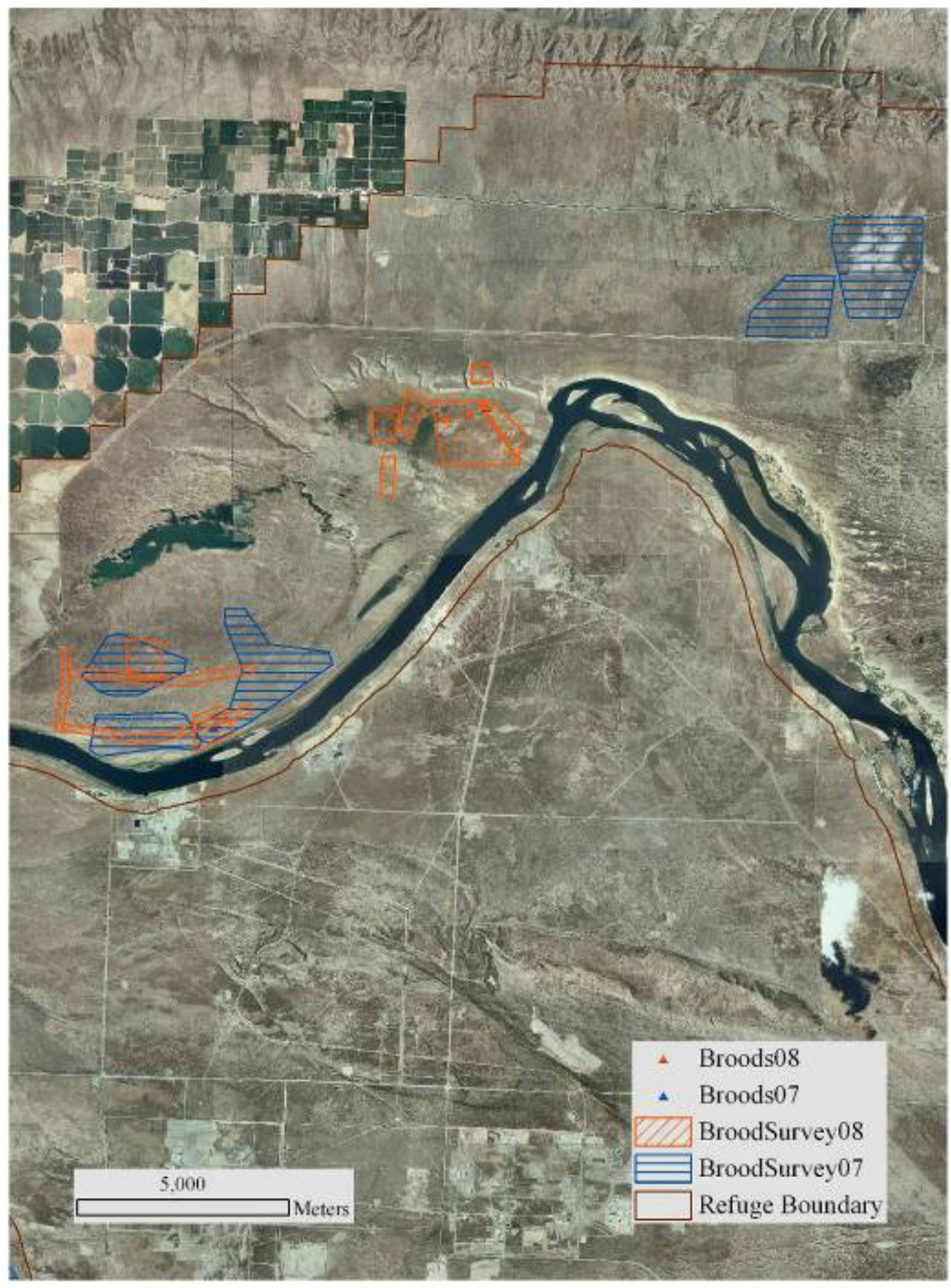

Figure 7. Brood surveys and locations at the Saddle Mountain Unit of Hanford Reach National Monument, south-central Washington, 2007-08. 


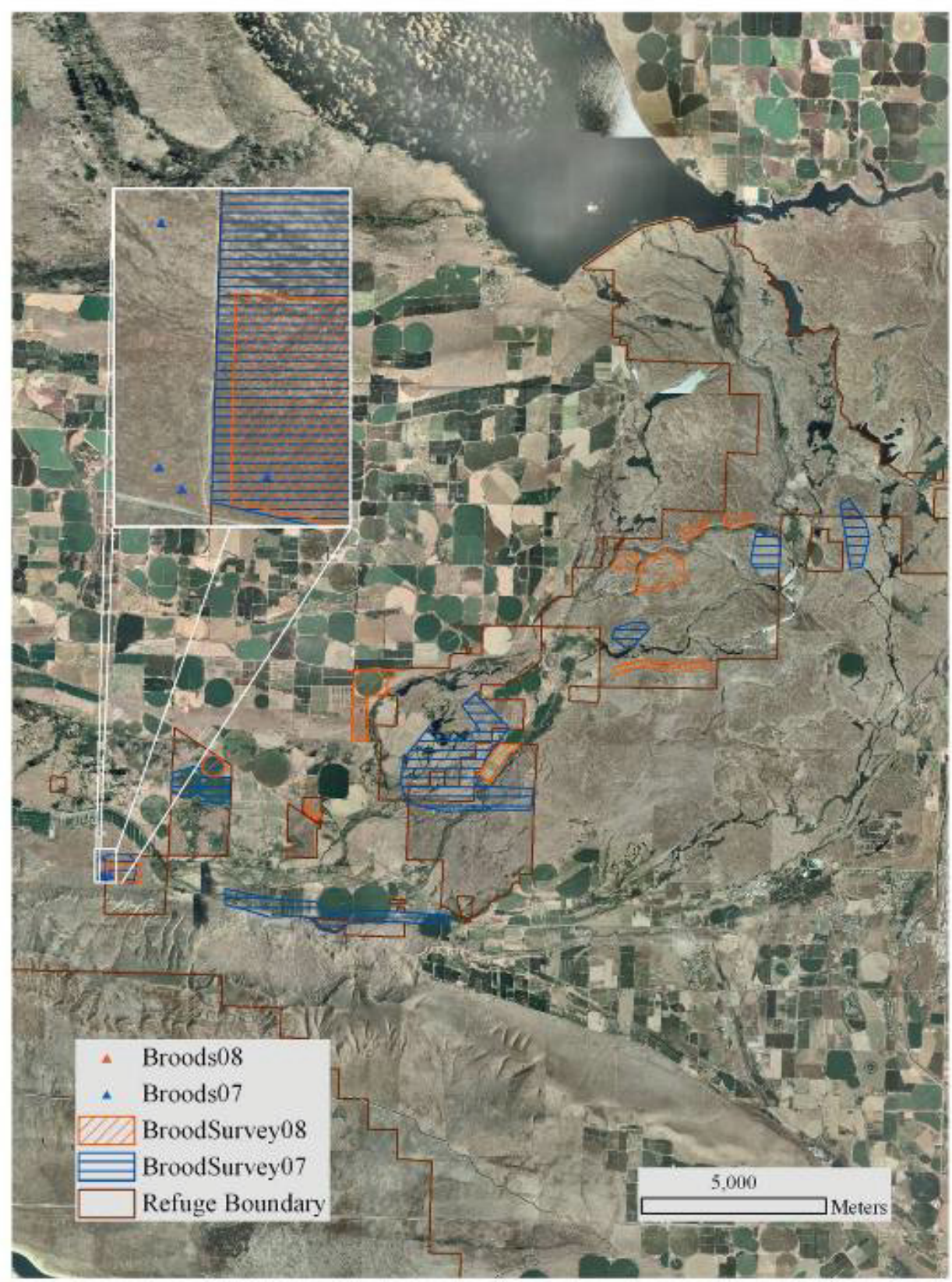

Figure 8. Brood surveys and locations at Columbia National Wildlife Refuge, south-central Washington, 2007-08. Enlarged area shows brood locations. 


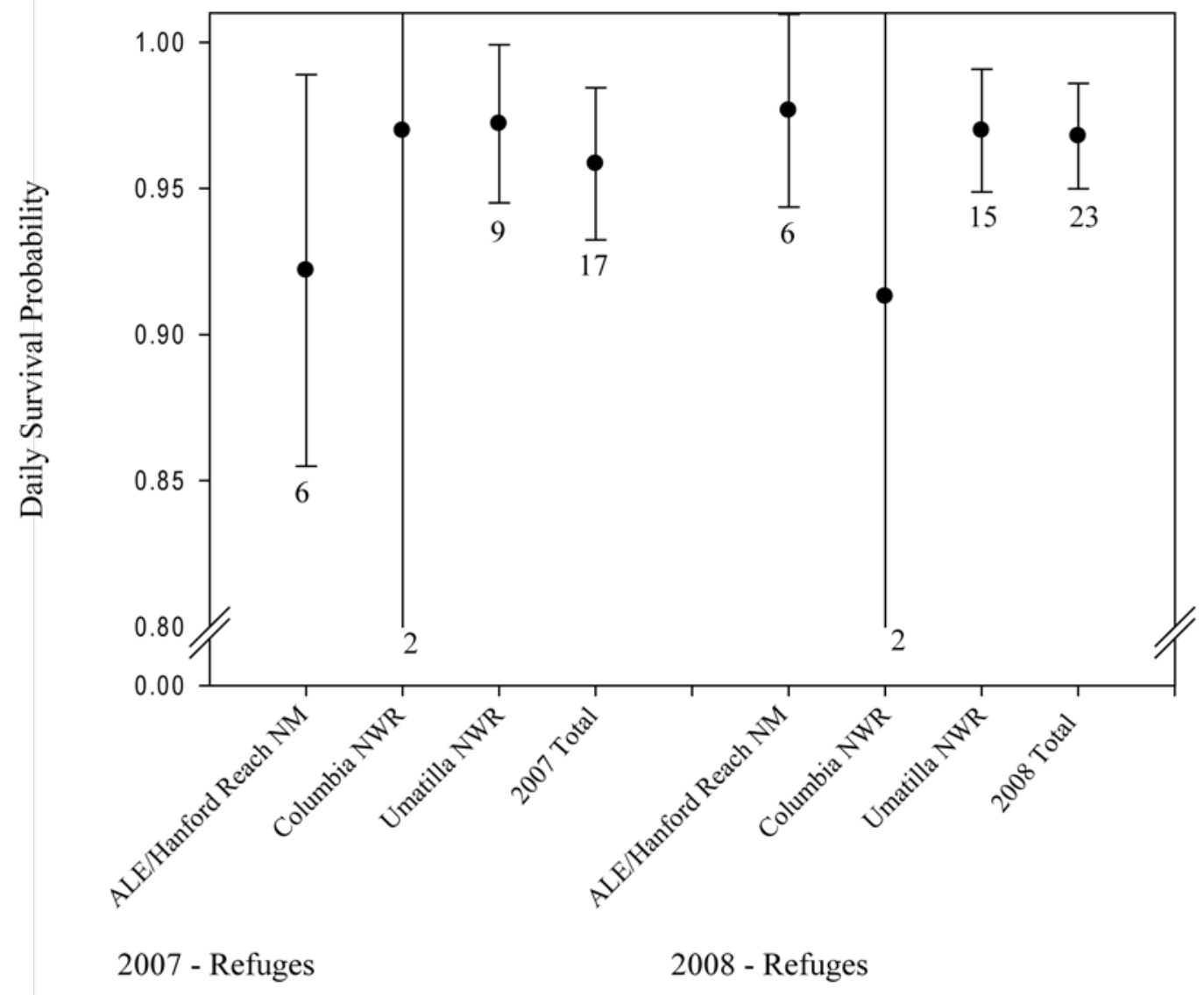

Figure 9. Daily survival probability ( \pm 2 standard errors; Johnson, 1979) of long-billed curlew nests by year and management unit on three national wildlife refuges in the Columbia Basin south-central Washington and north-central Oregon, 2007-08.

Sample size is provided at the bottom of each error bar. 


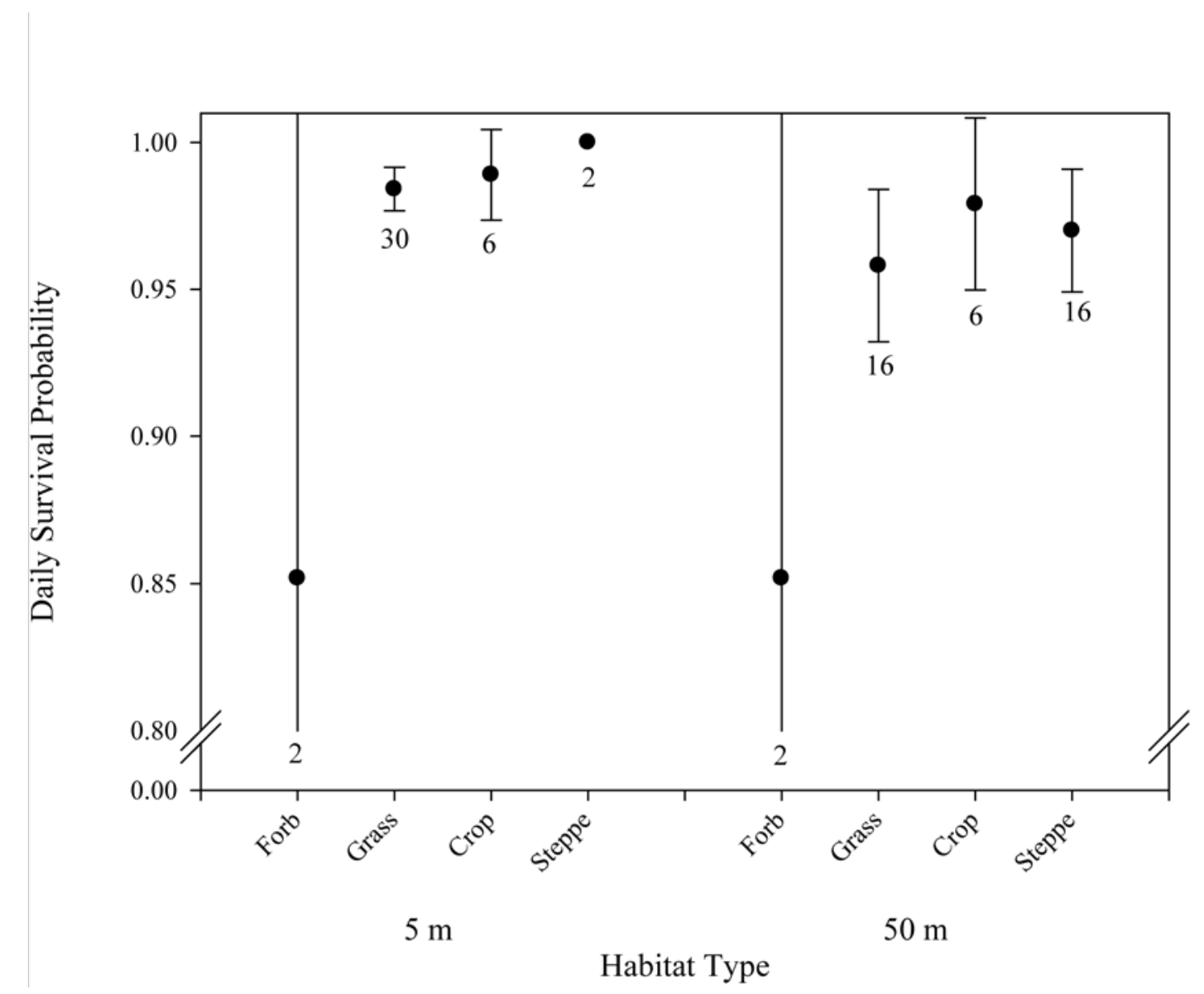

Figure 10. Daily survival probability ( \pm 2 standard errors; Johnson, 1979) of long-billed curlew nests per year for habitat categories at 5- and 50-m scales. Sample size is provided at the bottom of each error bar. 


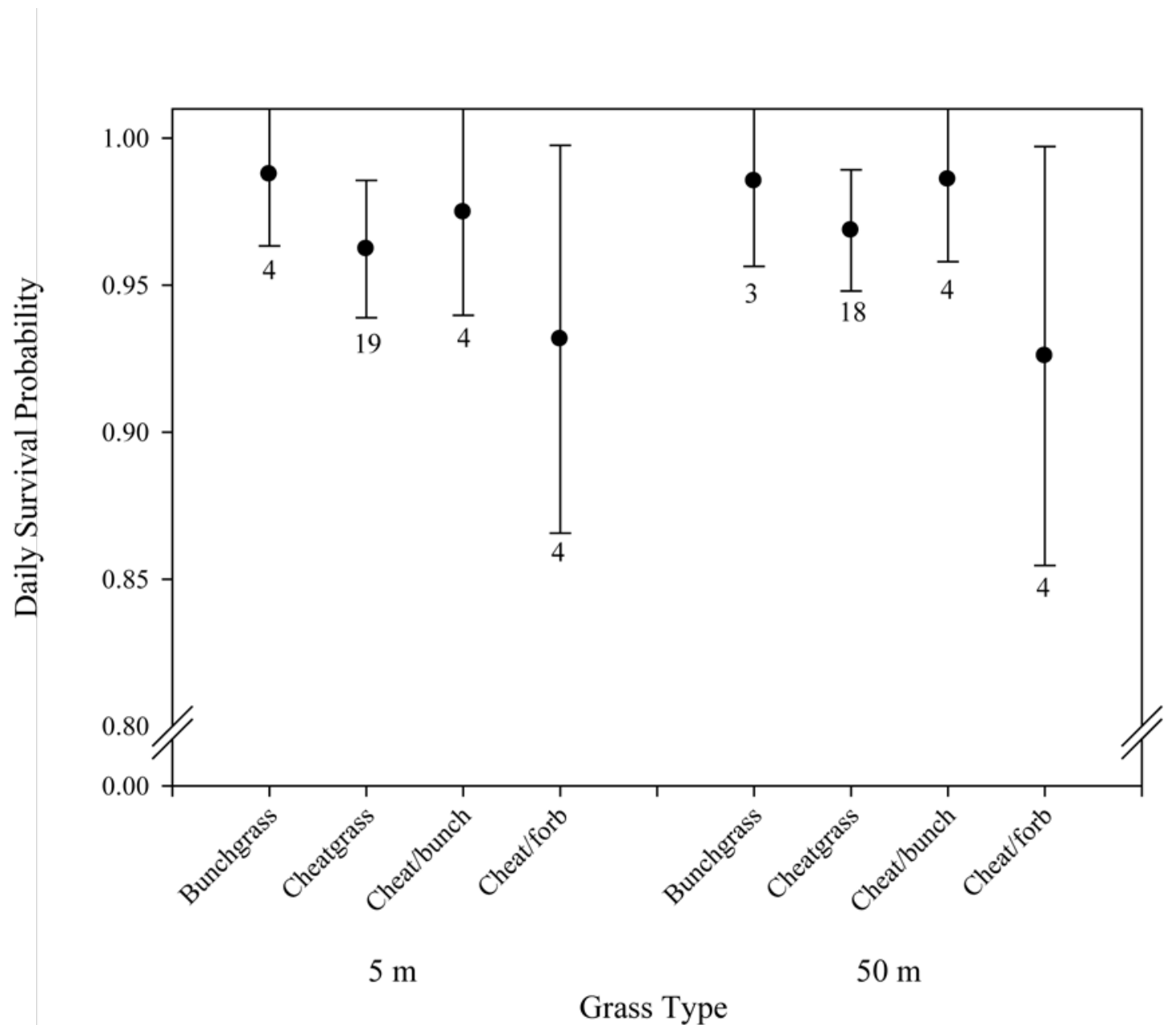

Figure 11. Daily survival probability ( \pm 2 standard errors; Johnson, 1979) of long-billed curlew nests in four primary grass types at 5- and 50-m scales. Sample size is provided at the bottom of each error bar. 
Table 1. Curlew pair densities (pairs per hectare) for each management unit, south-central Washington and north-central Oregon, 2007-08.

[NWR, National Wildlife Refuge. ha, hectare. unk, unknown. n/a, not applicable]

\begin{tabular}{|c|c|c|c|c|c|c|}
\hline \multirow[b]{2}{*}{$\begin{array}{c}\text { NWRI } \\
\text { Management unit }\end{array}$} & \multicolumn{3}{|c|}{2007} & \multicolumn{3}{|c|}{2008} \\
\hline & $\begin{array}{l}\text { Number } \\
\text { of pairs }\end{array}$ & $\begin{array}{c}\text { Area } \\
\text { (ha) }\end{array}$ & Density & $\begin{array}{l}\text { Number } \\
\text { of pairs }\end{array}$ & $\begin{array}{c}\text { Area } \\
\text { (ha) }\end{array}$ & Density \\
\hline Saddle Mountain $^{1}$ & 4 & 30,693 & 0.000130 & 2 & 23,430 & 0.000085 \\
\hline $\mathrm{ALE}^{1}$ & 13 & 8,403 & 0.001547 & 7 & 5,396 & 0.001297 \\
\hline Paterson $^{2}$ & 5 & 724 & 0.006906 & 7 & 724 & 0.009669 \\
\hline McCormack North ${ }^{2}$ & unk & $\mathrm{n} / \mathrm{a}$ & $\mathrm{n} / \mathrm{a}$ & 5 & 824 & 0.006068 \\
\hline McCormack South ${ }^{2}$ & 6 & 566 & 0.010601 & 8 & 566 & 0.014134 \\
\hline Columbia NWR & 4 & $\mathrm{n} / \mathrm{a}$ & $\mathrm{n} / \mathrm{a}$ & 6 & $\mathrm{n} / \mathrm{a}$ & $\mathrm{n} / \mathrm{a}$ \\
\hline McNary NWR & 0 & $\mathrm{n} / \mathrm{a}$ & $\mathrm{n} / \mathrm{a}$ & 0 & $\mathrm{n} / \mathrm{a}$ & $\mathrm{n} / \mathrm{a}$ \\
\hline
\end{tabular}

${ }^{1}$ Hanford Reach National Monument

${ }^{2}$ Umatilla NWR 
Table 2. Effort, method, and number of breeding pairs and broods detected on three national wildlife refuges in the Columbia Basin, south-central Washington and north-central Oregon, 2007.

[NWR, National Wildlife Refuge. unk, unknown; N, no; Y, yes]

\begin{tabular}{|c|c|c|c|c|c|c|c|c|c|c|c|}
\hline \multirow[b]{2}{*}{$\begin{array}{c}\text { NWRI } \\
\text { Management } \\
\text { unit }\end{array}$} & \multirow[b]{2}{*}{$\begin{array}{l}\text { Search } \\
\text { area }\end{array}$} & \multirow[b]{2}{*}{$\begin{array}{l}\text { Effort } \\
\text { level }\end{array}$} & \multicolumn{3}{|c|}{ Search method } & \multirow{2}{*}{$\begin{array}{c}\text { Estimated } \\
\text { breeding } \\
\text { pairs }\end{array}$} & \multicolumn{3}{|c|}{ Confirmed initiations } & \multirow{2}{*}{$\begin{array}{c}\text { Total } \\
\text { initiations } \\
\text { confirmed }\end{array}$} & \multirow{2}{*}{$\begin{array}{l}\text { Minimum } \\
\text { broods } \\
\text { detected }\end{array}$} \\
\hline & & & $\begin{array}{c}\text { Focal } \\
\text { observation }\end{array}$ & $\begin{array}{l}\text { Targeted } \\
\text { rope- } \\
\text { drag }\end{array}$ & $\begin{array}{c}\text { Systematic } \\
\text { rope-drag }\end{array}$ & & $\begin{array}{l}\text { Nests } \\
\text { found }\end{array}$ & $\begin{array}{c}\text { Broods } \\
<5 \text { days } \\
\text { old }\end{array}$ & $\begin{array}{c}\text { Depredated } \\
\text { eggshell }\end{array}$ & & \\
\hline Columbia NWR & Seeps Lake & med & $\mathrm{Y}$ & $\mathrm{N}$ & $\mathrm{N}$ & 1 & 1 & 0 & 0 & 1 & 0 \\
\hline Columbia NWR & $\begin{array}{l}\text { Long Lake } \\
\text { Hutchinson }\end{array}$ & low & $\mathrm{Y}$ & $\mathrm{N}$ & $\mathrm{N}$ & 0 & 0 & 0 & 0 & 0 & 0 \\
\hline Columbia NWR & Lake & med & $\mathrm{Y}$ & $\mathrm{N}$ & $\mathrm{N}$ & 1 & 1 & 0 & 0 & 1 & 0 \\
\hline Columbia NWR & 15.1 Road & low & $\mathrm{N}$ & $\mathrm{N}$ & $\mathrm{Y}$ & unk & 0 & 0 & 0 & 0 & 0 \\
\hline Columbia NWR & $\begin{array}{l}\text { Corfu } \\
\text { Crab Creek }\end{array}$ & low & $\mathrm{N}$ & $\mathrm{N}$ & $\mathrm{Y}$ & unk & 0 & 0 & 0 & 0 & 0 \\
\hline $\begin{array}{l}\text { Columbia NWR } \\
\text { Saddle }\end{array}$ & $\begin{array}{l}\text { West } \\
\text { Saddle }\end{array}$ & low & $\mathrm{Y}$ & $\mathrm{N}$ & $\mathrm{N}$ & 2 & 0 & 1 & 0 & 1 & 1 \\
\hline Mountain $^{1}$ & Mountain & high & $\mathrm{Y}$ & $\mathrm{Y}$ & $\mathrm{N}$ & 4 & 0 & 0 & 1 & 1 & 1 \\
\hline $\mathrm{ALE}^{1}$ & ALE North & med & $\mathrm{Y}$ & $\mathrm{N}$ & $\mathrm{N}$ & 3 & 1 & 0 & 0 & 1 & 0 \\
\hline $\mathrm{ALE}^{1}$ & Water Tanks & med & $\mathrm{Y}$ & $\mathrm{N}$ & Y & 4 & 2 & 0 & 0 & 2 & 0 \\
\hline ALE $^{1}$ & 112 Road & med & Y & $\mathrm{N}$ & Y & 2 & 0 & 0 & 0 & 0 & 0 \\
\hline $\mathrm{ALE}^{1}$ & $\begin{array}{l}111 \text { Road } \\
\text { Paterson }\end{array}$ & high & $\mathrm{Y}$ & $\mathrm{Y}$ & $\mathrm{N}$ & 4 & 3 & 0 & 0 & 3 & 3 \\
\hline Paterson ${ }^{2}$ & $\begin{array}{l}\text { North } \\
\text { McCormack }\end{array}$ & high & $\mathrm{Y}$ & $\mathrm{Y}$ & $\mathrm{N}$ & 5 & 1 & 0 & 0 & 1 & 2 \\
\hline McCormack $^{2}$ & $\begin{array}{l}\text { South } \\
\text { McCormack }\end{array}$ & high & $\mathrm{Y}$ & $\mathrm{N}$ & $\mathrm{N}$ & 6 & 6 & $2^{3}$ & 1 & 9 & 5 \\
\hline McCormack $^{2}$ & North & med & $\mathrm{N}$ & $\mathrm{N}$ & $\mathrm{Y}$ & unk & 2 & 1 & 0 & 3 & 3 \\
\hline Total & & & & & & 32 & 19 & 2 & 2 & 23 & 15 \\
\hline
\end{tabular}

${ }^{1}$ Hanford Reach National Monument.

${ }^{2}$ Umatilla NWR.

${ }^{3}$ Likely nest bowls were found near both broods. 
Table 3. Effort, method, and number of breeding pairs and broods detected on three national wildlife refuges in the Columbia Basin, south-central Washington and north-central Oregon, 2008.

[NWR, National Wildlife Refuge. unk, unknown; N, no; Y, yes]

\begin{tabular}{|c|c|c|c|c|c|c|c|c|c|c|c|}
\hline \multirow[b]{2}{*}{$\begin{array}{c}\text { NWRI } \\
\begin{array}{c}\text { Management } \\
\text { unit }\end{array} \\
\end{array}$} & \multirow[b]{2}{*}{$\begin{array}{c}\text { Search } \\
\text { area }\end{array}$} & \multirow[b]{2}{*}{$\begin{array}{l}\text { Effort } \\
\text { level }\end{array}$} & \multicolumn{3}{|c|}{ Search method } & \multirow{2}{*}{$\begin{array}{c}\text { Estimated } \\
\text { breeding } \\
\text { pairs }\end{array}$} & \multicolumn{3}{|c|}{ Confirmed initiations } & \multirow{2}{*}{$\begin{array}{c}\text { Total } \\
\text { initiations } \\
\text { confirmed }\end{array}$} & \multirow{2}{*}{$\begin{array}{c}\text { Minimum } \\
\text { broods } \\
\text { detected }\end{array}$} \\
\hline & & & $\begin{array}{c}\text { Focal } \\
\text { observation }\end{array}$ & $\begin{array}{l}\text { Targeted } \\
\text { rope- } \\
\text { drag }\end{array}$ & $\begin{array}{l}\text { Systematic } \\
\text { rope-drag }\end{array}$ & & $\begin{array}{l}\text { Nests } \\
\text { found }\end{array}$ & $\begin{array}{l}\text { Broods } \\
<5 \text { days } \\
\text { old }\end{array}$ & $\begin{array}{c}\text { Depredated } \\
\text { eggshell }\end{array}$ & & \\
\hline Columbia NWR & Seeps Lake & med & $\mathrm{Y}$ & $\mathrm{Y}$ & $\mathrm{N}$ & 1 & 1 & 0 & 0 & 1 & 0 \\
\hline Columbia NWR & $\begin{array}{l}\text { Long Lake } \\
\text { Hutchinson }\end{array}$ & med & $\mathrm{Y}$ & $\mathrm{N}$ & $\mathrm{Y}$ & 0 & 0 & 0 & 0 & 0 & 0 \\
\hline Columbia NWR & Lake & high & $\mathrm{Y}$ & $\mathrm{Y}$ & $\mathrm{N}$ & 2 & 0 & 0 & 0 & 0 & 0 \\
\hline Columbia NWR & 15.1 Road & med & $\mathrm{Y}$ & $\mathrm{N}$ & $\mathrm{Y}$ & 1 & 0 & 0 & 0 & 0 & 0 \\
\hline Columbia NWR & $\begin{array}{l}\text { Corfu } \\
\text { Crab Creek }\end{array}$ & med & $\mathrm{Y}$ & $\mathrm{N}$ & $\mathrm{Y}$ & 1 & 1 & 0 & 0 & 1 & 0 \\
\hline Columbia NWR & $\begin{array}{l}\text { West } \\
\text { Saddle }\end{array}$ & med & $\mathrm{Y}$ & $\mathrm{Y}$ & $\mathrm{Y}$ & 1 & 0 & 0 & 0 & 0 & 0 \\
\hline Saddle Mountain $^{1}$ & Mountain & low & $\mathrm{Y}$ & $\mathrm{Y}$ & $\mathrm{Y}$ & 2 & 0 & 1 & 0 & 1 & 2 \\
\hline $\mathrm{ALE}^{1}$ & $\begin{array}{l}\text { ALE North } \\
\text { Water }\end{array}$ & low & $\mathrm{Y}$ & $\mathrm{N}$ & $\mathrm{N}$ & 1 & 0 & 0 & 0 & 0 & 0 \\
\hline $\operatorname{ALE}^{1}$ & Tanks & low & $\mathrm{Y}$ & $\mathrm{N}$ & $\mathrm{N}$ & 1 & 0 & 0 & 0 & 0 & 0 \\
\hline $\mathrm{ALE}^{1}$ & 112 Road & high & $\mathrm{Y}$ & $\mathrm{Y}$ & $\mathrm{Y}$ & 2 & 3 & 2 & 0 & 3 & 2 \\
\hline $\mathrm{ALE}^{1}$ & $\begin{array}{l}111 \text { Road } \\
\text { Paterson }\end{array}$ & high & $\mathrm{Y}$ & $\mathrm{Y}$ & $\mathrm{Y}$ & 3 & 3 & 1 & 0 & 3 & 2 \\
\hline Paterson $^{2}$ & $\begin{array}{l}\text { North } \\
\text { McCormack }\end{array}$ & high & $\mathrm{Y}$ & $\mathrm{Y}$ & $\mathrm{Y}$ & 7 & 6 & 3 & 0 & 6 & 4 \\
\hline McCormack $^{2}$ & $\begin{array}{l}\text { South } \\
\text { McCormack }\end{array}$ & high & $\mathrm{Y}$ & $\mathrm{Y}$ & $\mathrm{Y}$ & 8 & 6 & 1 & 0 & 6 & 1 \\
\hline McCormack $^{2}$ & North & high & $\mathrm{Y}$ & $\mathrm{Y}$ & $\mathrm{Y}$ & 5 & 3 & 2 & 0 & 3 & 2 \\
\hline Total & & & & & & 35 & 23 & 10 & 0 & 24 & 13 \\
\hline
\end{tabular}

${ }^{1}$ Hanford Reach National Monument

${ }^{2}$ Umatilla NWR 
Table 4. Apparent and Mayfield nest success of long-billed curlews by year and management unit on three national wildlife refuges in the Columbia Basin, south-central Washington and north-central Oregon, 2007-08.

[National wildlife refuge: Sample size is included in parentheses with the first number representing 2007, followed by 2008]

\begin{tabular}{|c|c|c|c|c|}
\hline & \multicolumn{2}{|c|}{2007} & \multicolumn{2}{|c|}{2008} \\
\hline National wildlife refuge & $\begin{array}{l}\text { Apparent } \\
\text { success } \\
\text { (percent) }\end{array}$ & $\begin{array}{l}\text { Mayfield } \\
\text { success } \\
\text { (percent) }\end{array}$ & $\begin{array}{c}\text { Apparent } \\
\text { success } \\
\text { (percent) }\end{array}$ & $\begin{array}{l}\text { Mayfield } \\
\text { success } \\
\text { (percent) }\end{array}$ \\
\hline Hanford Reach NM $(\mathrm{n}=6,6)$ & 17 & 6.3 & 67 & 44.7 \\
\hline Columbia NWR $(\mathrm{n}=2,2)$ & 50 & 35.1 & 0 & 4.5 \\
\hline Umatilla NWR $(\mathrm{n}=9,15)$ & 63 & 38.2 & 47 & 35.3 \\
\hline Total & 41 & 23.6 & 48 & 32.9 \\
\hline
\end{tabular}

Table 5. Mean values ( \pm 1 standard error) of vegetation characteristics for successful and unsuccessful long-billed curlew nests.

[veg, vegetation; dist., distance; n, number of nests; cm, centimeter, m, meter, ${ }^{\circ}$, degree]

\begin{tabular}{|l|l|l|}
\hline \multicolumn{1}{|c|}{ Characteristics } & \multicolumn{1}{|c|}{$\begin{array}{c}\text { Successful nests } \\
(\mathbf{n}=\mathbf{1 8})\end{array}$} & \multicolumn{1}{|c|}{$\begin{array}{c}\text { Unsuccessful nests } \\
(\mathbf{n}=\mathbf{2 1})^{1}\end{array}$} \\
\hline Veg max $(\mathrm{cm})$ & $36.5( \pm 10.1)$ & $35.7( \pm 18.8)$ \\
\hline Veg mean $(\mathrm{cm})$ & $14.0( \pm 9.6)$ & $14.2( \pm 7.0)$ \\
\hline Slope $\left(^{\circ}\right)$ & $2.6( \pm 2.7)$ & $2.0( \pm 2.4)$ \\
\hline Aspect $\left(^{\circ}\right)$ & $230.6( \pm 137.9)$ & $233.5( \pm 117.5)$ \\
\hline Dist. to tree/shrub (m) & $99.5( \pm 128.6)$ & $79.5( \pm 138.0)$ \\
\hline Dist. to road (m) & $292.0( \pm 183.9)$ & $305.6( \pm 218.8)$ \\
\hline Dist. to water $(\mathrm{m})$ & $2,332.2( \pm 2,323.3)$ & $2,202.6( \pm 2,444.0)$ \\
\hline Dist. to agriculture $(\mathrm{m})$ & $3,870.0( \pm 5,832.9)$ & $4,222.7( \pm 5,223.8)$ \\
\hline${ }^{1}$ One nest was omitted from analysis due to lack of vegetation measurements. \\
\hline
\end{tabular}


Table 6. Long-billed curlew nest success (Mayfield method) per year by main grass components at 5- and 50-m scales.

[n, number of nests; m, meter]

\begin{tabular}{|l|c|c|r|c|r|c|}
\cline { 2 - 7 } \multicolumn{1}{c|}{} & \multicolumn{2}{c|}{$\mathbf{2 0 0 7}$} & \multicolumn{2}{c|}{$\mathbf{2 0 0 8}$} & \multicolumn{2}{c|}{ COMBINED } \\
\hline \multicolumn{1}{|c|}{$\mathbf{5} \mathbf{~} \mathbf{n}$} & $\mathbf{n}$ & Success & $\mathbf{n}$ & Success & $\mathbf{n}$ & Success \\
\hline Bunchgrass & 0 & & 4 & 0.657 & 4 & 0.657 \\
\hline Cheatgrass & 9 & 0.262 & 10 & 0.280 & 19 & 0.271 \\
\hline Cheat/bunch & 3 & 0.300 & 1 & 1 & 4 & 0.421 \\
\hline Cheat/forb & 0 & & 4 & 0.090 & 4 & 0.090 \\
\hline $50 \mathrm{~m}$ & & & & & & \\
\hline Bunchgrass & 0 & & 3 & 0.607 & 3 & 0.607 \\
\hline Cheatgrass & 8 & 0.390 & 10 & 0.292 & 18 & 0.338 \\
\hline Cheat/bunch & 2 & 0.384 & 2 & 1 & 4 & 0.617 \\
\hline Cheat/forb & 0 & & 4 & 0.073 & 4 & 0.073 \\
\hline
\end{tabular}




\section{Appendix A. Long-Billed Curlew Nest Study Protocol}

\section{A. Hartman, February 2007}

\section{Sexing Long-Billed Curlews}

With a little practice, long-billed curlews can be accurately sexed in the field. Sexing of curlews will be an important component of nest-searching activities (see below). Long-billed curlews can be sexed by differences in bill length and shape. A useful rule of thumb is that, in profile, the bill of the female is more than three times the length of the head; in the male, the bill is three times the length of the head or less. Furthermore, the male bill has a slightly more pronounced curve than the female bill. In the male, the bill appears to curve about midway from the head to the tip, whereas in the female, the bill appears to be quite straight until a few centimeters from the bill tip. When a pair is seen together, overall body size also will help indicate sex as the female can be as much as one-third larger than the male. Below is a photograph of a curlew pair. The female is in the foreground.

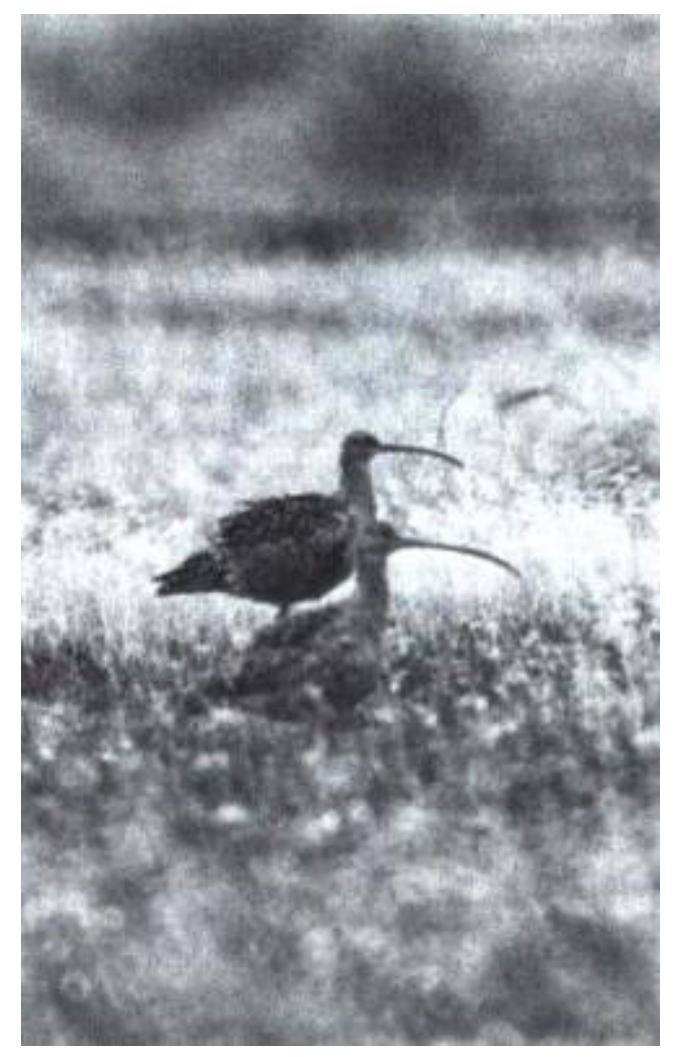

Photograph is taken from Allen (1980). The ecology and behavior of the Long-Billed Curlew in southeastern Washington. Wildlife Monograph 73. 


\section{Nest Searches}

In order to maximize the number of nests found, two methods will be used for nest searching: behavioral observations and rope-dragging.

\section{Behavioral Observations}

During nest construction and egg-laying (late March, early April), curlews are quite active around the nest site and make frequent trips to tend to newly laid eggs. During this time, we will observe curlews from a distance using 20-60x spotting scopes and record locations of nest-building activity. Observations will be conducted in the early morning, 0600 to 1000 hours, as this is the time when curlews are most active in nest building.

There is no set protocol for finding nests; it takes skill and luck. The most important thing is to be aware of the birds all around you. Often you will find the nest of a bird that you were not really watching, but that you happened to see out of the corner of your eye walk to a nest. Another thing to remember is to make sure that you are far enough from the birds so that they feel comfortable going back to their nest. A minimum of $100 \mathrm{~m}$ is a good rule of thumb but this can vary by individual curlew.

The behaviors to look for include attempted copulations, copulations, scraping, and grasstossing. A male will attempt to court a female by stroking her back feathers vigorously. If the female bites or pecks at the male and does not allow the male to mount, she is not yet receptive and egg-laying probably is a few days away. It is best to leave these individuals alone and return in a few days to reassess their status. Curlews copulate frequently just before and during egg-laying. Thus, all observed copulations should be noted and copulating birds should be watched closely. Actual nest-building behaviors include scraping and grass-tossing. Scraping is the behavior in which the male or the female squats over a potential nest site and pushes his/her breast into the ground while rapidly kicking dirt out behind him/her. The bird may then stand, change position, and then scrape again. A bird may do this several times in succession at the same site. Grass-tossing is when a male or female picks up pieces of vegetation with their bill and flicks it over their shoulder and into the nest bowl. A bird can spend several minutes tossing grass into a potential nest site.

Observing birds scrape and/or grass-toss does not necessarily ensure that a nest has been found. Curlews often scrape and even grass toss at multiple sites before the female chooses a spot to lay the first egg. However, if a pair is seen spending a great deal of time at the same spot (especially over consecutive days), then it is most likely a nest. Before the clutch is complete, the male (and less often the female) also will periodically sit on the eggs for short bouts. If you see a male or female sit down and assume an incubation posture for more than 10 minutes, then you probably have a nest with an egg in it. It is important not to scare a bird away from a potential nest site before laying begins as they may react to the disturbance by moving to another nest site. Thus, caution should be used in approaching nests that are found during nest building.

Later in the season, once most clutches have been completed, nests are extremely hard to find. Curlews hold very tight to the nest and so the only way to observe a parent going to the nest is to watch an incubation exchange. Curlews often only exchange twice a day. Females incubate during the day and will relieve their male (who incubates all night) early in the morning. Therefore, it is best to watch a female between 6 a.m. and 8 a.m. until she flies and/or walks to the nest. Conversely, males will relieve their females in the late afternoon, usually between 4 p.m. and 6 p.m., although it may be later. Therefore, it is best to watch a male during this time until he goes to the nest. 


\section{Rope-Dragging}

Later in the season, once incubation has commenced, we will use a rope-dragging technique to flush incubating birds off the nest. Rope dragging can be done with a 3- or 4-person crew, depending on technician availability. Two technicians hold opposite ends of an approximately 30-m rope (about 1.5$\mathrm{cm}$ diameter) and systematically walk through each target area to ensure complete coverage. One or two additional technicians walk a few meters behind the rope to watch for curlews flushing from the nest. It may be possible for a two-person team to conduct the rope-dragging alone as long as they are able to monitor the rope and see any flushing birds. Rope-dragging can be conducted at all hours of the day but may be most effective if done during the hottest hours, as this almost ensures that an adult will be on the nest.

In areas where there are a lot of shrubs, rope-dragging will be replaced with systematic walks. Technicians will walk approximately 5-m apart in an effort to flush any incubating birds. Technicians also can use long poles to tap the ground immediately surrounding them as they walk so as to increase the chances of flushing tight-sitting birds.

Nests that have already been located should be given a wide berth of at least $30 \mathrm{~m}$ so as to minimize disturbance to the incubating adults.

\section{Monitoring Nests}

Once located, nests will be marked and monitored at least once a week until failure or hatch. If cattle feces are present, they can be stacked (about 3 layers high) approximately $10 \mathrm{~m}$ on either side of the nest bowl. However, DO NOT use any cattle feces within $10 \mathrm{~m}$ of the nest to limit disturbance at the nest site. If cattle feces or other natural objects are not available, short wooden stakes may be used instead. Whenever possible, nest status (that is, active or inactive) will be determined from a distance to limit disturbance to the incubating birds. This can be done by approaching the nest from the direction of one nest marker and, using binoculars or a spotting scope, seeing if a bird is incubating. The exact location of the nest will be known because it should be directly between the two nest markers (fig. A1). If no bird is seen, the observer should slowly walk closer to the nest, checking for the presence of the bird again when at the first nest marker. If a bird is still not seen, the observer should walk to the nest to see if eggs are still present. If the nest has been disturbed (for example, all eggs are gone, eggs have been eaten in the nest, or one or more eggs are missing), the nature of the disturbance should be recorded. The date of each nest check needs to be recorded for nest survival analysis.

At each nest, we will determine nest initiation date (NID) and measure a suite of vegetation and habitat variables. If a nest is found with one egg, we will assume that to be the date of initiation. For nests found with two to three eggs, NID will be estimated by back-counting assuming an egg-laying interval of 1.5 days. Therefore, if a nest is found with three eggs on April 14, then we would estimate that it was initiated on April 11. If a nest is found with two eggs on April 14, then we would estimate that it was initiated on April 12. For nests found after clutch completion (that is, with four eggs), eggs will be floated (fig. A2, table A1) to determine stage of development and to estimate clutch completion date. Then, counting back 5 days will yield an estimate for NID.

To float eggs, carefully place a curlew egg into a transparent cup or beaker and note how it floats relative to the egg flotation chart (fig. A2). Eggs need to be placed in the container gently because eggs from a newly laid clutch (Stage 1) will quickly sink to the bottom. Because there may be some variability in floating stage among eggs within a clutch, all eggs should be floated. Once the incubation stage is determined, use the age midpoint table to estimate nest age since clutch completion. For example, say a curlew nest is found with four eggs on April 22. All four eggs float at Stage 4 of the egg 
flotation chart. Using the age midpoint table (A1), we would estimate that the eggs have been incubated for 11 days. This corresponds with a April 12 clutch completion date. Back-counting 5 days for egglaying yields an April 8 nest initiation date.

Long-billed curlew nests hatch after about 28 days of incubation. Thus, as nests approach the estimated hatch date, they should be checked more frequently to determine if hatch occurred. Beginning on about day 26 of incubation, nests should be visited at least every other day until egg starring or pipping occurs. Starring is when eggs show a noticeable star-shaped cracking pattern that signifies that hatch has begun. Pipping is when a hole has formed in the egg and often the chick can be seen and even heard inside the egg. Starring and pipping occur on the wide end of the egg and not the pyriform end.

\section{Nest Vegetation Measurements}

At each nest, we will record visual obstruction or effective vegetation height (EVH) by noting the lowest band on a 1-m tall Robel pole marked in 2.5-cm increments, which can be seen at a distance of $1.5 \mathrm{~m}$ and a height of $30 \mathrm{~cm}$. Four measurements of effective vegetation height will be recorded, one for each of the four cardinal directions, to gage vegetation height evenness (fig.A3 ). The vegetation measurements will be conducted as follows:

1. The Robel pole is placed at one of the four numbered points in figure A3. The Robel pole is a 5$\mathrm{cm}$ diameter pole that has alternating $2.5 \mathrm{~cm}$ black and white bands.

2. While one person holds the Robel pole in place, a second person walks $1.5 \mathrm{~m}$ away from the nest and places a $30 \mathrm{~cm}$ observation pole down. A rope attached to both the Robel pole and the observation pole that is cut to the correct length will ensure that the observer is exactly $1.5 \mathrm{~m}$ from the Robel pole. The observer then notes the lowest band on the Robel pole that he/she can see.

3. Repeat this process at the other three points in figure A3.

A diagram of the Robel pole measurement is in figure A4.

In addition, we will record maximum vegetation height (the highest point the vegetation reaches within the $1-\mathrm{m}^{2}$ box shown in figure A3) mean vegetation height (the average height of the vegetation within the $1-\mathrm{m}^{2}$ box shown in figure A3), soil moisture as dry (no water content), damp (soil is moist to the touch), or wet (standing water is present). Habitat variables to be recorded will include distance to nearest standing water, distance to shrub or tree, distance to road, land use, etc. Vegetation and habitat data at the nest will be recorded immediately after hatch for successful nests or when hatch would have occurred for failed nests. 


\section{Long-Billed Curlew Nest Data Example.}

The following data will be recorded for every nest found and will be entered on a nest data sheet (see below).

\section{Nest ID \#}

2. Location (Plot \#, Refuge?)

3. GPS coordinates

4. Date Found

5. Initiation Date and how this was determined

6. Completion date and how this was determined

7. Clutch Size

8. Overall Nest Fate

9. Veg Max, Veg Mean, Soil Moisture, Distance to Water, Shrub, Road

10. Effective Vegetation Height $(\mathrm{EVH})$ at the four points around the nest

11. A complete nest history under Nest Chronology

Nest chronology will be recorded as follows. In the example below (table A2), the nest was found on April 14 with three eggs. By counting back, assuming a 1.5 day egg-laying interval, we estimate that the nest was initiated on April 11. An (I) is entered on this date and April 11 is entered in the Nest Initiation Date box. In addition, a (1) is entered nest to the date to signify how the nest initiation date was determined. In the event that a nest is found with one egg, a zero would be entered in parentheses next to the nest initiation date. Next, the clutch completion date is estimated to be April 15, assuming 5 days of egg-laying from the nest initiation date. A 3 is entered as the method in which clutch completion was determined. The nest below was checked on April 21 and April 28 and was found to be active both times as noted by the letter A entered on both days. In addition, on April 21 the nest was visually inspected and found to have four eggs, which floated at Stage 3 (F3) according to the egg flotation chart. The nest check on May 6 was found to have been depredated, and so an X is entered for this date. Lastly, vegetation was measured on May 12, and a V is entered on this date.

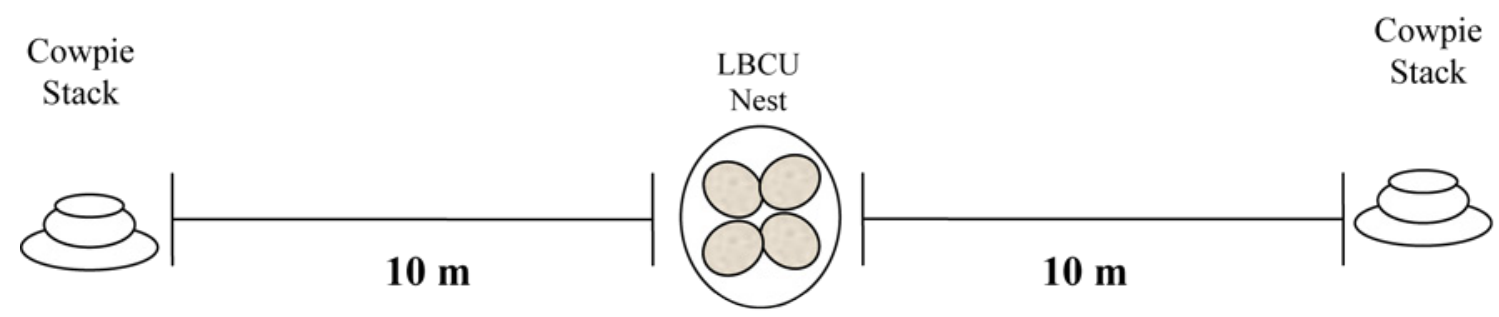

Figure A1. Method for marking nest location. 


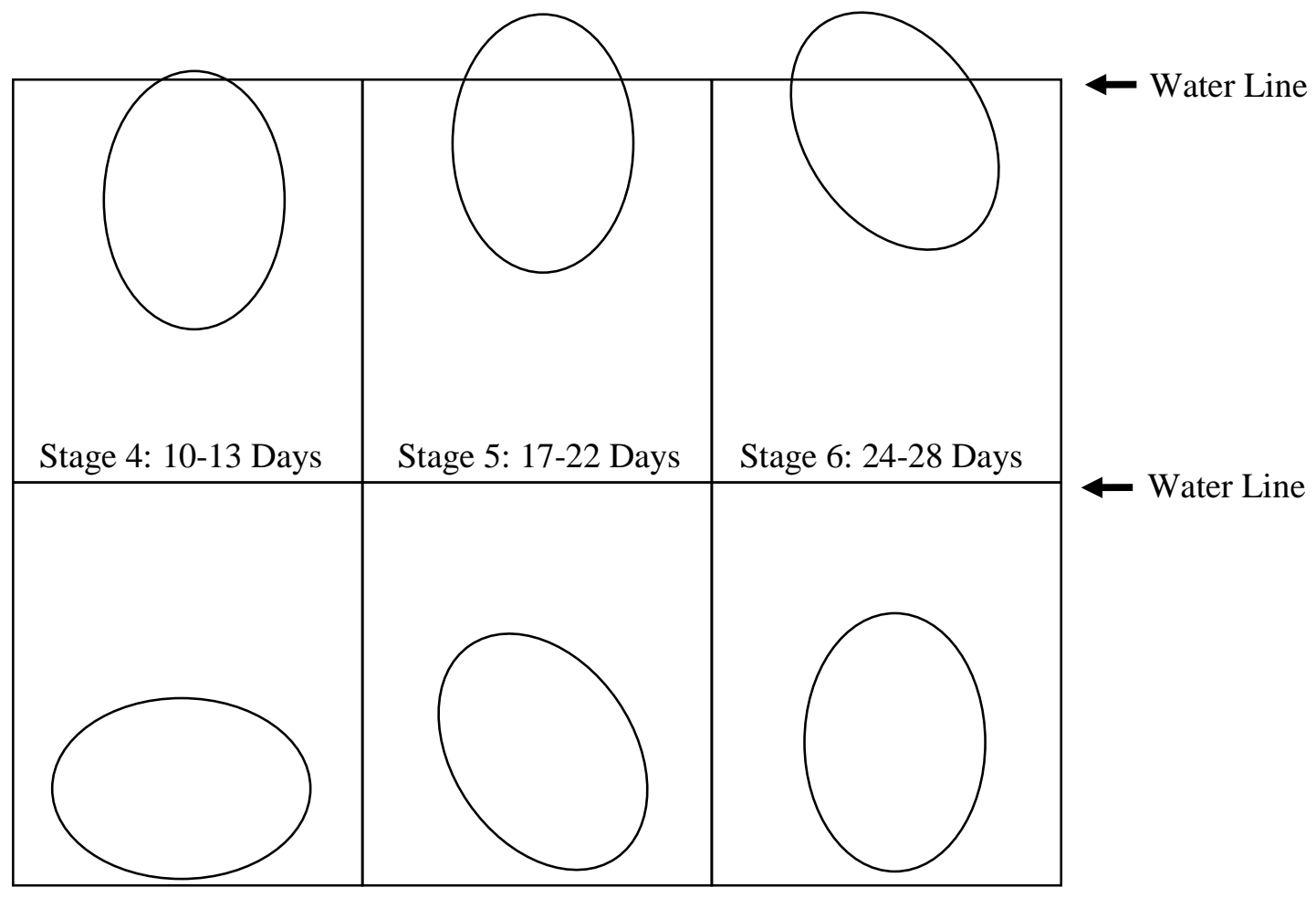

Stage 1: 0-1 Day

Stage 2: 1-6 Days

Stage 3: 7-9 Days

Figure A2. LBCU Egg Flotation Chart for Estimating Incubation Stage. 


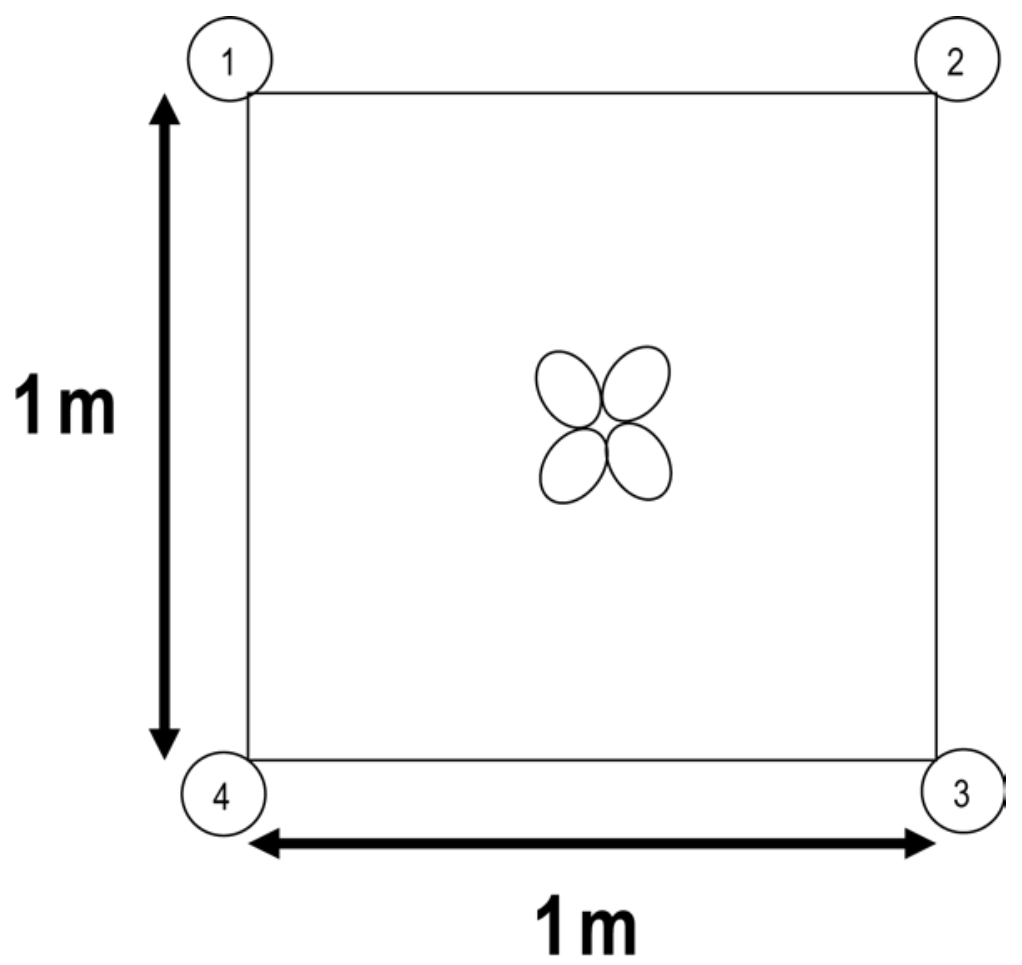

Figure A3. Locations of the four visual obstruction measurements around a long-billed curlew nest. 


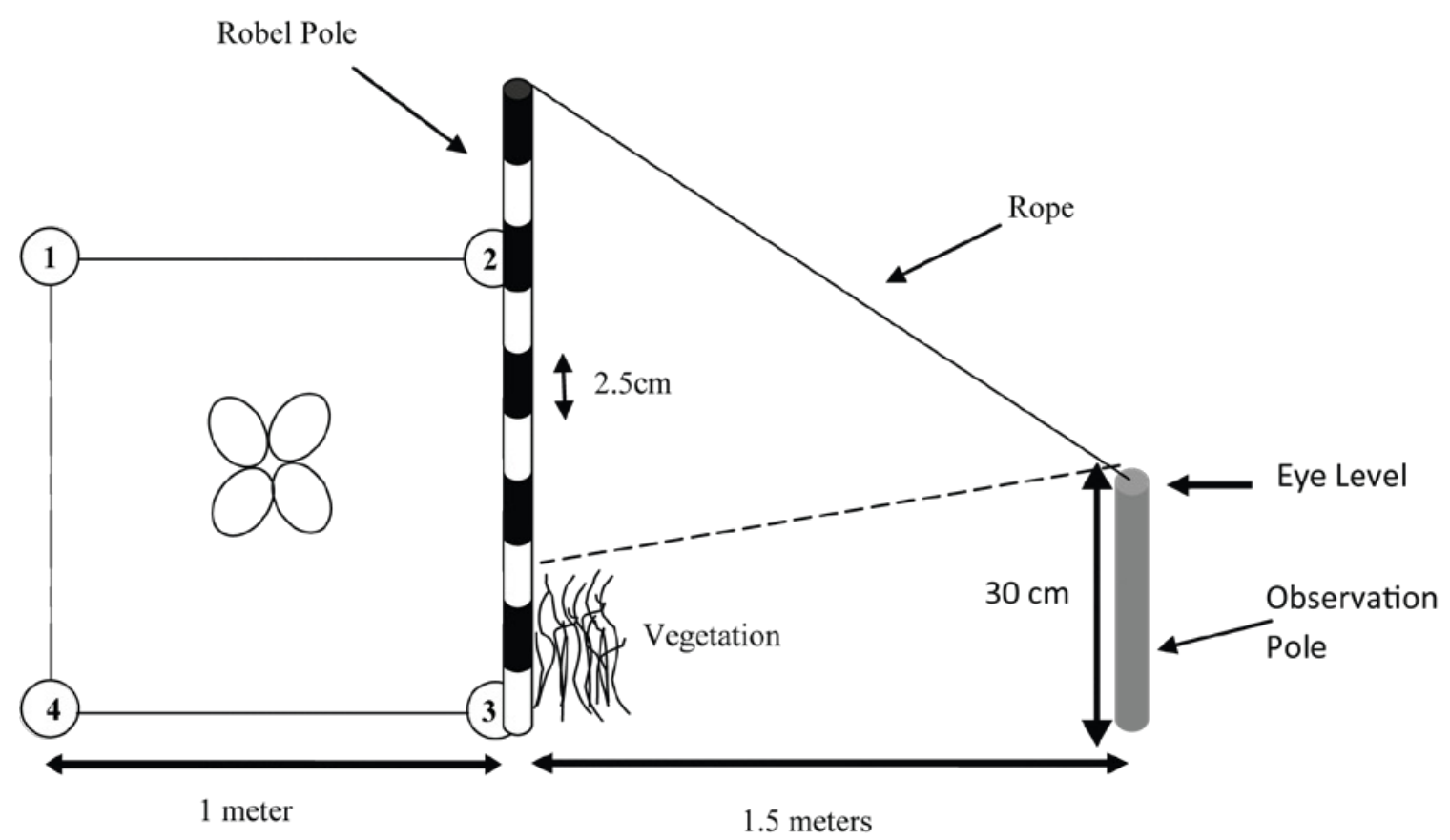

Figure A4. Diagram of the visual obstruction measurement using a Robel pole. Dashed line represents the observer's line of sight and in this example indicates that the third band on the Robel pole is the lowest band that can be seen.

Table A1. Age midpoints used to estimate nest age and nest initiation date.

\begin{tabular}{|c|c|c|}
\hline Stage & $\begin{array}{l}\text { Days since } \\
\text { clutch } \\
\text { completion }\end{array}$ & Description of egg \\
\hline 1 & 0 & Lies on the long side of the egg at the bottom of the container. \\
\hline 2 & 3 & Lies at a $45^{\circ}$ angle (pyriform side down) at the bottom of the \\
\hline 3 & 8 & Lies with pyriform end pointing down at the bottom of the \\
\hline 4 & 11 & $\begin{array}{l}\text { Pyriform end pointing down and the wide end of the egg is just } \\
\text { breaching the water surface. }\end{array}$ \\
\hline 5 & 19 & $\begin{array}{l}\text { Pyriform end pointing down and the wide end of the egg is high } \\
\text { above the water surface. }\end{array}$ \\
\hline 6 & 26 & $\begin{array}{l}\text { Lies at a } 45^{\circ} \text { angle with the wide end of the egg high above the } \\
\text { water surface. }\end{array}$ \\
\hline
\end{tabular}


Table A2. Example nest sheet.

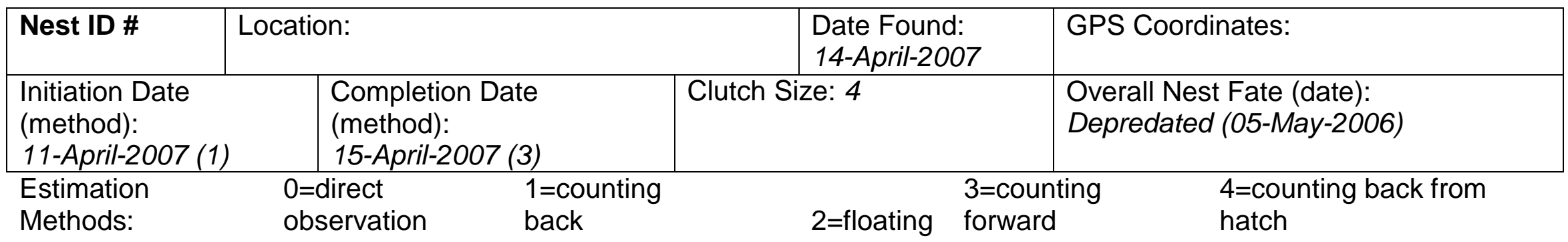

\section{Nest}

Characteristics

\begin{tabular}{|c|c|c|c|c|c|}
\hline Veg Max & Veg Mean & $\begin{array}{c}\text { Soil } \\
\text { Moisture }\end{array}$ & $\begin{array}{c}\text { Dist. To } \\
\text { Water }\end{array}$ & $\begin{array}{c}\text { Dist. to Tree or } \\
\text { Shrub }\end{array}$ & $\begin{array}{c}\text { Dist. To } \\
\text { Road }\end{array}$ \\
\hline $12 \mathrm{~cm}$ & $8 \mathrm{~cm}$ & Dry & $250 \mathrm{~cm}$ & $50 \mathrm{~m}$ & $1000 \mathrm{~m}$ \\
\hline
\end{tabular}

\section{Visual}

\section{Obstruction}

\begin{tabular}{|c|c|}
\hline Point & EVH \\
\hline 1 & 1 \\
\hline 2 & 2 \\
\hline 3 & 1 \\
\hline 4 & 1 \\
\hline
\end{tabular}

\section{Egg Fates}

\begin{tabular}{|c|c|c|c|}
\hline Egg & $\begin{array}{c}\text { Egg } \\
\text { Fate }\end{array}$ & Date & $\begin{array}{c}\text { Embryo } \\
\text { Age }\end{array}$ \\
\hline 1 & 3 & $5 / 6 / 2006$ & N/A \\
\hline 2 & 3 & $5 / 6 / 2006$ & N/A \\
\hline 3 & 3 & $5 / 6 / 2006$ & N/A \\
\hline
\end{tabular}

\begin{tabular}{|c|c|c|c|}
\hline Egc & Fate Codes: & & oryo Age Codes: \\
\hline 0 & unknown & 0 & none \\
\hline 1 & hatch & \# & est. age \\
\hline & & 2 & \\
\hline 2 & inviable & 0 & full term \\
\hline & & 9 & \\
\hline 3 & pred-unk & 8 & not accessible \\
\hline & & 9 & \\
\hline 4 & pred-bird & 9 & not accessed \\
\hline 5 & pred-mamm & & \\
\hline 6 & trampled & & \\
\hline 7 & abandoned & & \\
\hline 8 & collect & & \\
\hline & died in & & \\
\hline 9 & hatch & & \\
\hline 10 & flooded & & \\
\hline 11 & crushed & & \\
\hline
\end{tabular}




\begin{tabular}{|l|l|l|l|}
\cline { 2 - 4 } & & & \\
\hline 4 & 3 & $5 / 6 / 2006$ & N/A \\
\hline
\end{tabular}

20 failed to hatch after 28 days inc.

\section{Nest}

Chronology

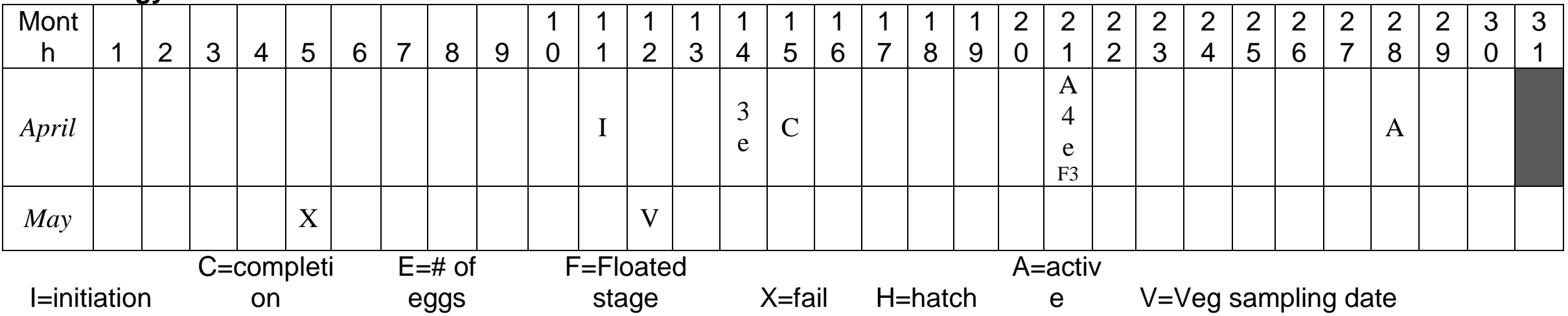




\section{Appendix B. Photographs of Long-Billed Curlew Chicks}

Photographs courtesy of A. Hartman.

Age 1 week:

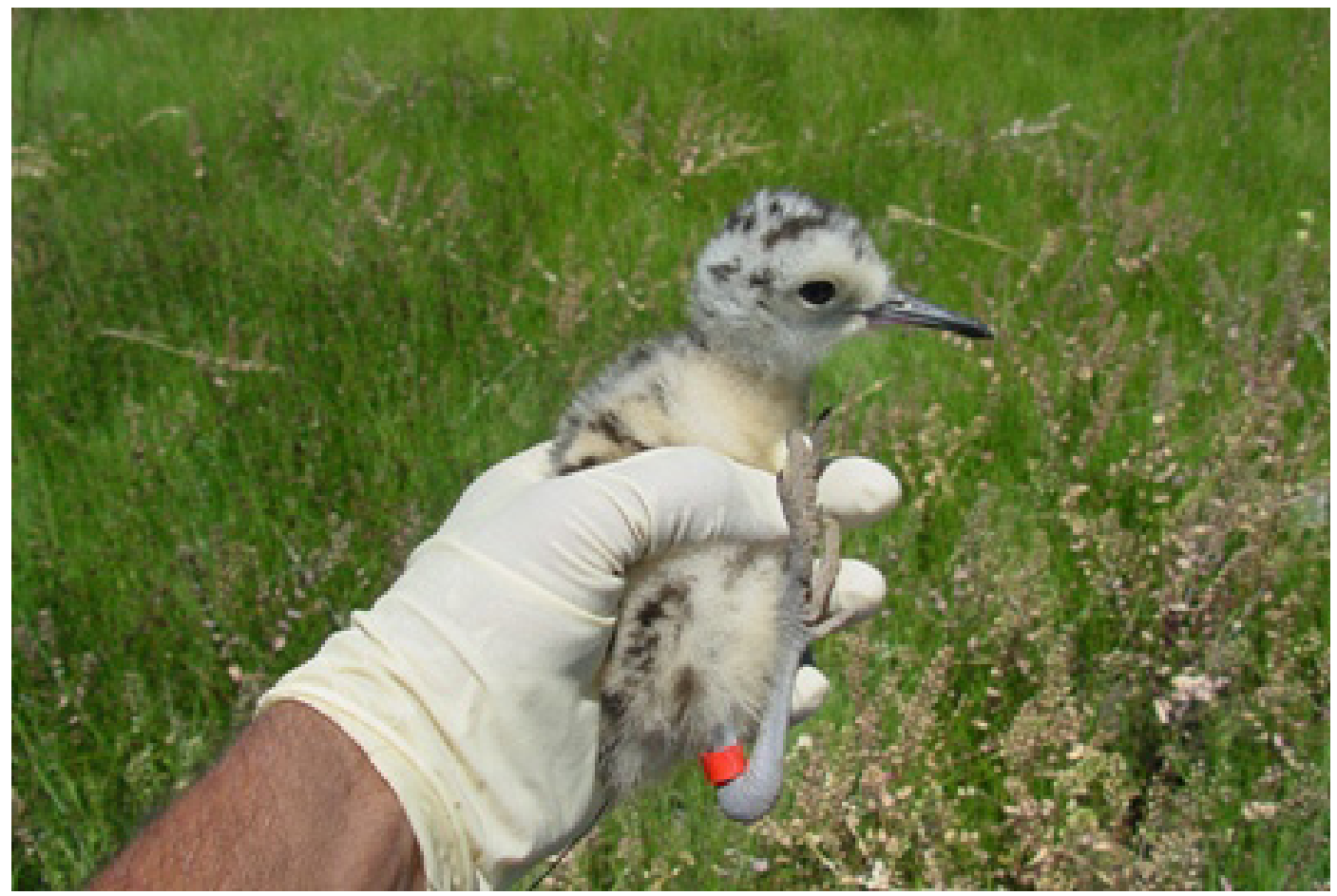

Age 2 weeks:

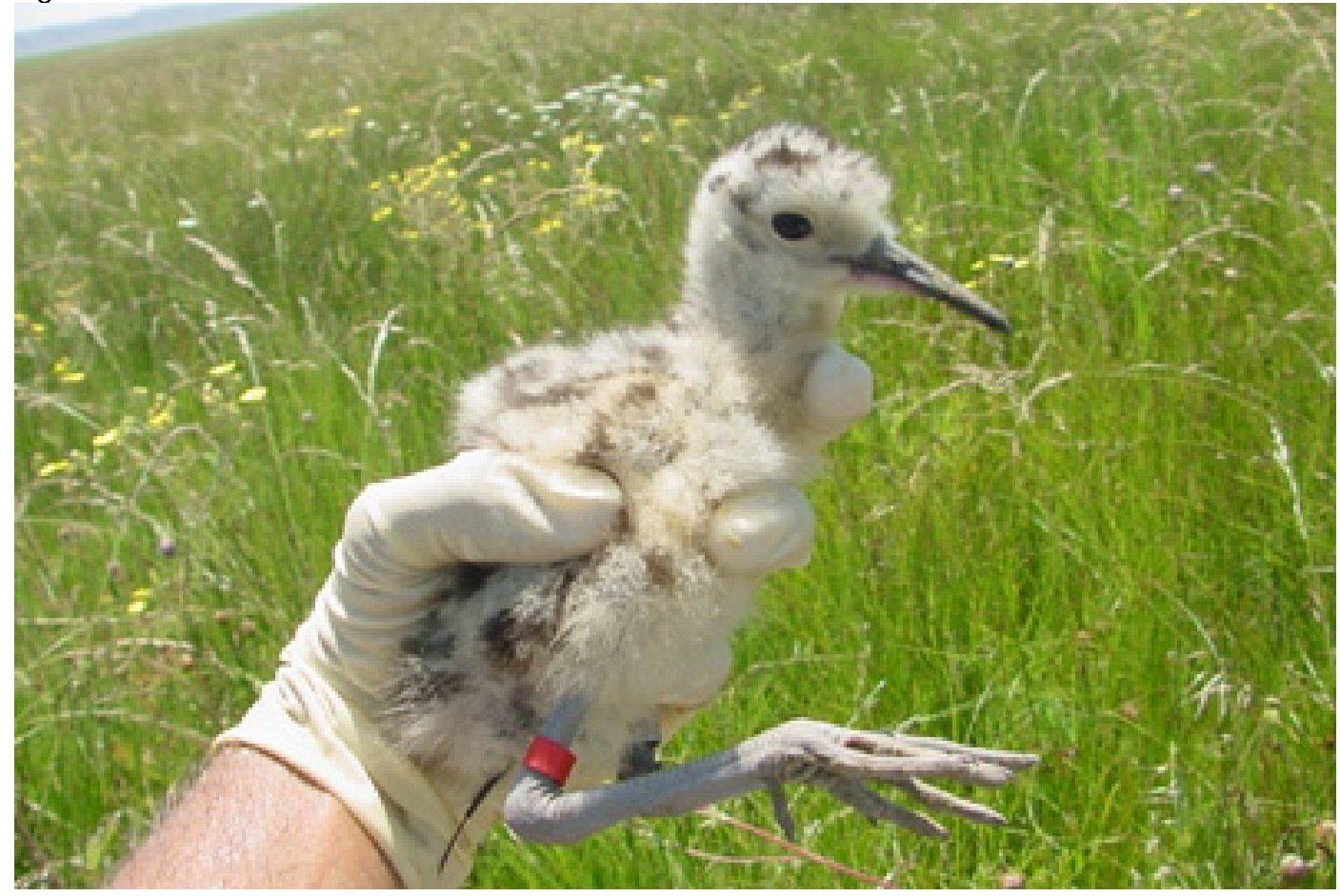


Age 3 weeks:

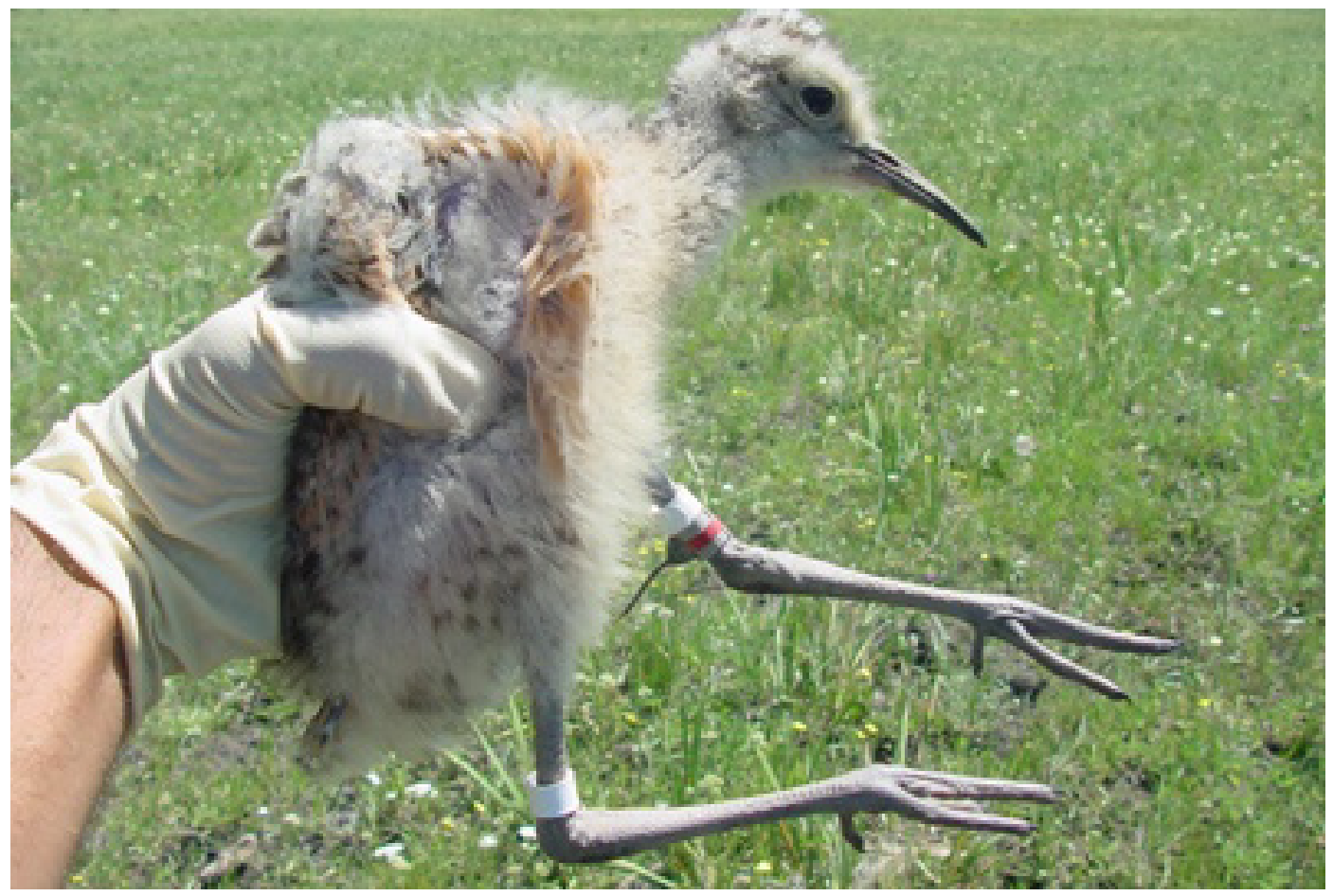

Age 4 weeks:

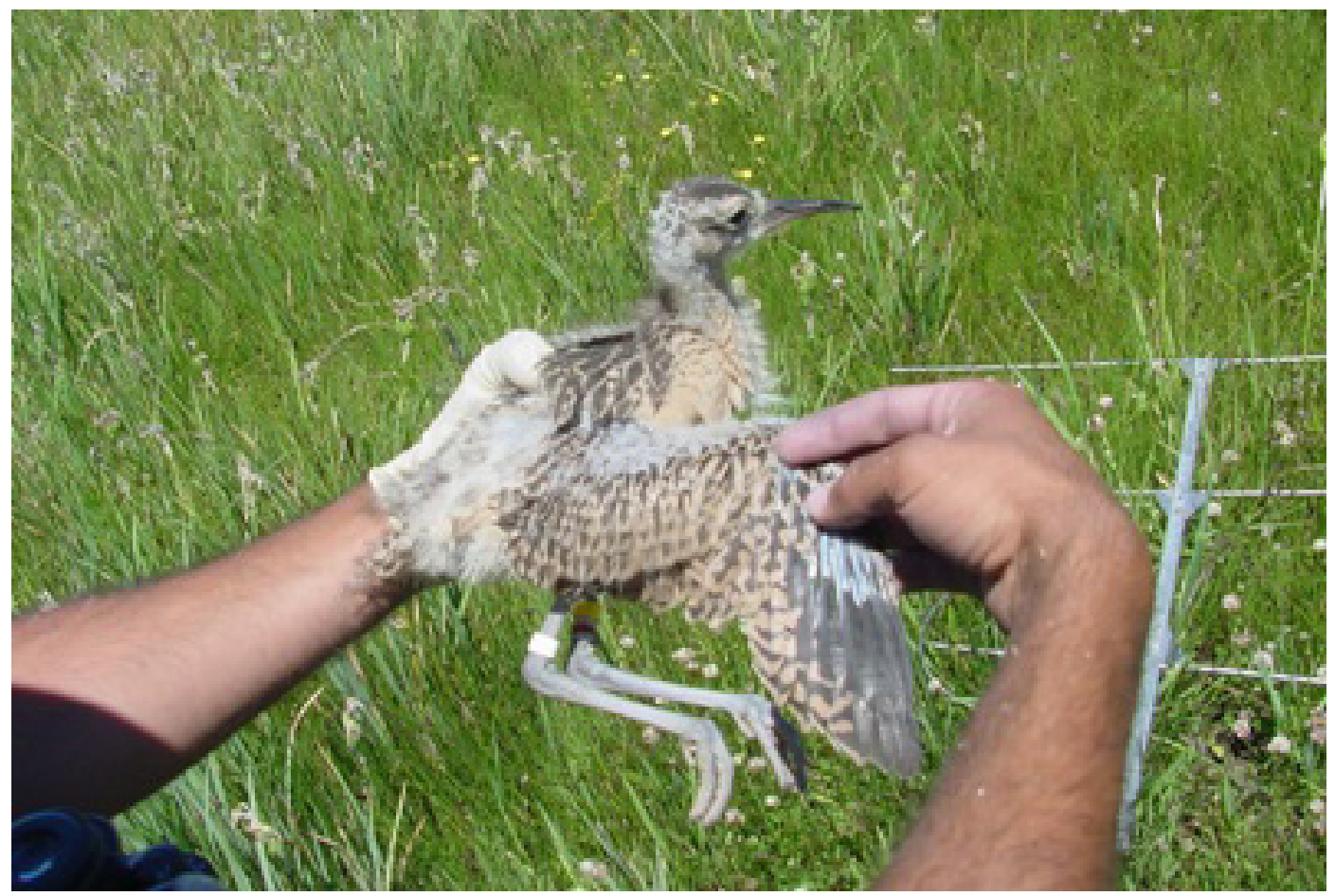


Publishing support provided by the U.S. Geological Survey Publishing Network, Tacoma Publishing Service Center

For more information concerning the research in this report, contact the Director, Forest and Rangeland Ecosystems Science Center 777 NW 9th St., Suite 400

Corvallis, OR 97330

http://fresc.usgs.gov/ 

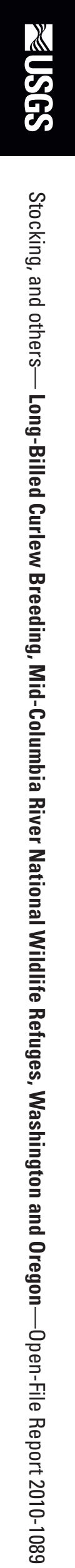